\title{
The Secret Politics of the Compatibilist Criminal Law
}

Anders Kaye*

\section{INTRODUCTION}

Many criminal theorists say that we have a "compatibilist" criminal law, by which they mean that in our criminal law a person can deserve punishment for her acts even if she does not have "genuinely" free will. This conception of the criminal law harbors and is driven by a secret politics, one that resists social change and idealizes the existing social order. In this Article, I map this secret politics. In so doing, I call into question the descriptive accuracy of the compatibilist account of the criminal law, and set the stage for a franker discussion of criminal punishment - one that recognizes that the perpetual struggle to say just who "deserves" punishment is driven as much by brute politics and the competition to allocate power and resources in society as by any independent moral logic.

$* * * * *$

It is sometimes said that our criminal law takes the "weak retributivist" view that an actor should not be punished unless she deserves to be punished. ${ }^{1}$ Since there is no desert without responsibility, ${ }^{2}$

* Associate Professor, Thomas Jefferson School of Law. I would like to thank Linda Berger, Lisa Bernstein, Deven Desai, Linda Keller, Dana Nelkin, Sandy Rierson, Steve Semeraro, Ben Templin, Claire Wright, Kaimi Wenger, Dan Williams, and all the participants in the Thomas Jefferson School of Law Scholarship Workshop, the Thomas Jefferson School of Law Junior Faculty Writing Workshop, and the University of Chicago Law School Scholarship Workshop class for their advice and suggestions regarding the arguments in this Article. I would also like to thank Dorothy Hampton, Andrea Patten, and Joseph Visic for outstanding research assistance.

1. Some theorists go further and argue that the criminal law adopts the "strong retributivist" principle that an actor must be punished if he deserves to be punished (while still holding that an actor cannot be punished if he does not deserve punishment). Other criminal theorists, including consequentialist theorists, say the criminal law does not follow any version of the retributivist principle. Still others take no position on this issue at all. On the various positions, see MICHAEL Moore, Placing Blame: A General Theory of the Criminal law 83-94 (1997), describing theories of the criminal law's function, and Michael Corrado, The Abolition of Punishment, 35 SufFolK U. L. Rev. 257, 262-66 (2001), describing hybrid theories. Because I believe that 
those who say we have a retributivist criminal law must also say something about how the law determines responsibility. One especially notorious problem here has to do with whether an actor must have "genuine" free will in order to be held responsible: if an actor was caused to act by forces beyond her control-e.g., if nature, nurture, circumstances, or some combination thereof, drove her inexorably to her act - will the criminal law hold her responsible?

Some criminal theorists say it will not: on their view, the criminal law takes the "originationist" approach, according to which an actor is not responsible for an act unless she was the original or ultimate cause of the act. ${ }^{3}$ Other theorists say the law may hold her responsible for her act: on their view, the criminal law takes the "compatibilist" approach,

commitment to retributive principles provides especially effective legitimating cover for state violence, I am skeptical of theories that downplay the role of retribution in contemporary criminal law. See infra Part IV.B.

2. Stephen J. Morse, Deprivation and Desert, in From Social Justice to Criminal Justice 115, 115-16 (William C. Heffernan \& John Kleinig eds., 2000).

3. The term originationism is not widely used, but "origination" language is becoming more common. See, e.g., Derk Pereboom, Living Without Free Will 4 (2001) ("[A] claim about origination ... might be formulated as follows ... an agent is not morally responsible for [a] decision if it is produced by a source over which she has no control."); Michael Corrado, Automatism and the Theory of Action, 39 EMORY L.J. 1191, 1192, 1212 (1990) (using origination language in discussion of voluntariness); Scott W. Howe, Reassessing the Individualization Mandate in Capital Sentencing: Darrow's Defense of Leopold and Loeb, 79 IowA L. REV. 989, 1019-21 (1994) (same); Michael McKenna, Source Incompatibilism, Ultimacy, and the Transfer of NonResponsibility, 38 AM. PHIL. Q. 37, 40 (2001) ("[I]f determinism is true, and agent's actions do not originate in her."); Derk Pereboom, Determinism al Dente, in FreE WILl 243, 245 n.7 (Derk Pereboom ed., 1997) ("[C]ompatibilists ignore a widespread attitude about our actions, that moral responsibility presupposes origination, or agent causation."); Gary Watson, Responsibility and the Limits of Evil: Variations on a Strawsonian Theme, in RESPONSIBILITY, CHARACTER, AND THE EMOTIONS: New EsSAYs IN MORAl PSyChology 256, 282 (Ferdinand Schoeman ed., 1987) ("[U]nless consent were undetermined, we would not truly be originators of our deeds. We would be merely products, and not, as it were, producers."); Roy C. Weatherford, Compatibilism and Incompatibilism, in THE OXFORD COMPANION TO PHILOSOPHY 144, 144 (Ted Honderich ed., 1995) ("The incompatibilist defends his view by arguing that a free act must involve . . . the freedom to choose called origination.").

Other terms have been used to identify the origination requirement. See, e.g., Pereboom, supra, at 54 (referring to the concept as the "causal history principle"); Susan L. Hurley, Debate: Luck, Responsibility, and the 'Natural Lottery', 10 J. POL. PHIL. 79, 82 (2002) ("[L]ack of control of causes is incompatible with responsibility," and "responsibility requires 'regressive control."'); Anders Kaye, Resurrecting the Causal Theory of the Excuses, 83 NEB. L. REV. 1116, 1117 (2005) (calling "the moral principle that actors cannot be blamed for conduct caused by forces beyond their control" the "control principle"); Dana K. Nelkin, Moral Luck, THE STANFORD ENCYCLOPEDIA OF PHILOSOPHY § 1, http://plato.stanford.edu/archives/spr2004/entries/moral-luck ("[C]ontrol principle" holds that "we are morally assessable only to the extent that what we are assessed for depends on factors under our control.").

Whatever term is used, the underlying principle is well-known. It is implicit in "hard determinism," also known as "incompatibilism" (the view that moral responsibility is incompatible with absolute determinism and that absolute determinism is true), Weatherford, supra, at 144, and libertarianism (the view that moral responsibility is inconsistent with absolute determinism, and that absolute determinism is false), Derk Pereboom, Introduction to FREE WILL, supra, at vii. 
according to which genuine free will is not a prerequisite for responsibility and a person can be held responsible for her act even if it was caused by forces beyond her control. ${ }^{4}$ Once, it was common for criminal theorists to say that the criminal law takes the originationist approach to responsibility. Today, however, it is more common to say we have a compatibilist criminal law.

This Article interrogates the compatibilist account of the criminal law. It does so in a very particular way. It does not directly challenge the descriptive accuracy of the compatibilist account, though there might be grounds for doing so $;{ }^{5}$ nor does it directly argue that compatibilism is "wrong" on the merits, though this might be possible too. ${ }^{6}$ Rather, this Article looks into the politics of the compatibilist criminal law. It contends that compatibilist and originationist criminal laws have different sorts of consequences for the allocation of power and resources in our society. I bring out these consequences to show the extent to which the compatibilist theory of the criminal law allies itself with a particular politics, and, in so doing, to encourage a more worldly debate about the meaning of criminal desert.

Part II sets the stage by describing the originationist and compatibilist accounts of the criminal law. Part III lays the foundation for the political critique. This Part compares the originationist and compatibilist approaches to responsibility and shows that compatibilists are less likely to attend to the ways hard social conditions (like poverty, inequality, and discrimination) influence human conduct. Part IV shows that this difference has political consequences in the context of the criminal law. Because originationism and compatibilism have such different attitudes toward hard social conditions, societies taking the compatibilist approach to criminal law will allocate power and resources differently than societies taking the originationist approach. As Part IV.A shows, a compatibilist criminal law is more likely to reinforce the existing social order. Its disregard for hard social conditions will disrupt popular recognition of the links between social conditions and crime, leaving citizens less likely to conceive and articulate challenges to the social order. Moreover, as Part II.B explains, a compatibilist criminal law is more conducive to the state's use of violence in defense of the social order. While originationist and compatibilist criminal laws both give the state broad authority to engage in the form of state violence

4. Among those who adopt this view, there is, of course, great debate about what criteria should be used to determine the actor's responsibility. See infra Part II.B.

5. See infra Part II.C.

6. Id. 
known as punishment, compatibilism's disregard for hard social conditions makes it more likely to approve the infliction of such violence on the socially disadvantaged, legitimating the use of state violence to disempower those at the bottom of the social order and to suppress their criticism of and resistance to the status quo.

The secret politics of the compatibilist criminal law, then, is that it is calibrated to defuse pressure for social change and to facilitate violent enforcement of the status quo. Having brought out this hidden politics, Part V proposes a new approach to the debate about criminal desert - an approach that is less likely to harbor such secrets. When participants in this reoriented debate say who they expect to see punished, they should identify the punished not just in the politically opaque language of responsibility, but also by reference to the role and status of the punished in the social order. They should say how their approach to desert will influence the allocation of resources and power in society. And they should say why we should desire or approve a society that allocates resources and power in the way they recommend.

\section{CRIMINAL THEORY'S PREFERENCE FOR COMPATIBILIST CRIMINAL LAW}

Many contemporary criminal theorists make the descriptive claim that we have a retributivist criminal law, in which an actor cannot be punished for an act unless he is morally responsible for that act. To flesh this claim out, however, criminal theorists must say something about how the criminal law determines moral responsibility. Here, theorists commonly say the criminal law determines responsibility by looking to aspects of the actor's choice, attitude, or character. ${ }^{7}$ But a complete retributivist account must also say something more: it must say what position the law takes on the notoriously difficult question of whether an actor will be held responsible for committing an act even if he did not act with "genuine" free will. ${ }^{8}$

There are two conventional answers here. The criminal law can take the originationist approach, in which an actor cannot be responsible for an act unless he acted with "genuine" free will, meaning that he-and

7. Regarding choice, attitude, and character theories, see infra notes 54-65 and accompanying text. It is not just retributivists who invoke the familiar frameworks of choice, attitude, and character theory; there are consequentialist flavors of these theories too. Consequentialists, however, are not directly confronted with the compatibilism-originationism question.

8. Michael Corrado, Notes on the Structure of a Theory of Excuses, 82 J. CRIM. L. \& CRIMINOLOGY 465, 468-69 (1991). 
not some force beyond his control - was the original or ultimate cause of his act. Alternatively, the criminal law can take the compatibilist approach, in which an actor can be held responsible for an act even if he did not "originate" it, so long as certain other criteria (having nothing to do with "genuine" free will) are satisfied. In our daily lives, many of us look like originationists - we talk as though we would excuse actors if we were convinced their acts were caused by forces beyond their control. Nevertheless, many criminal theorists say the criminal law takes the compatibilist approach: they say that, in our criminal law, it is no excuse that an act was caused by forces beyond the actor's control.

To set the stage for the political critique of the compatibilist criminal law, this Part describes the originationist and compatibilist accounts of the criminal law. The Parts that follow will explain why which sort of criminal law we have matters.

\section{A. The Originationist Account of the Criminal Law}

On one view, the criminal law takes an originationist approach to responsibility. Originationism holds that an actor is only responsible for an act if she acted with "genuine" "free will," such that her act "originated" with her, ${ }^{10}$ rather than with forces or circumstances beyond her control. ${ }^{11}$ The same idea is at work when we say that a person cannot be responsible unless she has "metaphysical,"12 "transcendental,"13 or

9. See P.F. Strawson, Freedom and Resentment, in FrEE WILL 72, 74 (Gary Watson ed., 2d ed. 2003) (using this language but rejecting the view it describes).

10. For sources using the origination formulation, see supra note 3 .

11. See Daniel DenNetT, Elbow Room 76 (1984) (noting that "[w]e want to be able to say of ourselves, as Harry Truman famously said, "the buck stops here," but rejecting the origination requirement); Michael Corrado, Addiction and Causation, 37 SAN DiEGo L. REv. 913, 915 (2000) ("If there is an unbroken causal history for a certain action, extending back to some event over which the agent had no control, then the agent is not (morally) responsible for that action." (internal footnote omitted)); Corrado, supra note 3, at 1201, 1225 ("I am responsible only for those things that are up to me; to be responsible, I must have some say in the matter. But I have no say in the matter of caused action." For an actor to be responsible for an act, "the volition . . . that leads to the behavior must be the first event in a causal chain . . . and must itself be uncaused."); Richard Delgado, "Rotten Social Background": Should the Criminal Law Recognize a Defense of Severe Environmental Deprivation?, 3 LAW \& INEQ. 9, 55 (1985) ("[B]lame is inappropriate when a defendant's criminal behavior is caused by extrinsic factors beyond his or her control."); Robert Kane, Introduction: The Contours of Contemporary Free Will Debates, in THE OXFORD HANDBOOK OF FREE WILL 3, 5 (Robert Kane ed., 2002) ("[W]e believe we have free will when ... the origin or source of our choices and actions is in us and not in anyone or anything else over which we have no control.").

12. Watson, supra note 3, at 281-82.

13. See R. Jay Wallace, Responsibility and the Moral Sentiments 13 (1994) (associating this expression with Kant). 
"contra-causal"14 free will, or that she must be the "ultimate" cause or source of her act, ${ }^{15}$ or that her act must be "governable by her self ad infinitum," over her act, or that she must "will" her act "without being caused to will it." 19 All these formulations gesture at the same thing: a person is only responsible for an act if she originates that act. If the act was caused by something - some force, event, or condition-beyond the actor's control, she is not responsible.

The moral intuition that animates originationism has been explained and evoked in a variety of ways. Academic philosophers sometimes state the intuition as though it were fundamental: "if an action results from a deterministic causal process that traces back to factors beyond the control of the agent, he is not morally responsible for the action." ${ }^{20}$ The intuition can also be evoked with a "transfer" argument, which emphasizes that if we are not responsible for the past and the laws of nature, and not responsible for the fact that the past and the laws of nature entail a particular future consequence, our "non-responsibility" should transfer to the future consequence as well. ${ }^{21}$ More colloquially, 'if agents' acts are caused by factors for which they are not responsible, then how can they be morally responsible for acting as a result of those factors?"; 22 and if an actor is to be blamed for his conduct, he "should be ultimately responsible ... 'ultimately' in the sense that nothing for which

14. Strawson, supra note 9, at 92; MOORE, supra note 1 , at 597.

15. See PEREBOOM, supra note 3 , at xv ("[M] $]$ oral responsibility requires actions to have . . causal histories that make agents ultimate sources of their actions."); see also McKenna, supra note 3 , at 40-41 (describing the "ultimacy condition," which holds that a person is not responsible for her acts if she is not the "ultimate source" of her acts).

16. SusAn WOLF, FREEdOM Within REASON 34-35 (1990).

17. See S.L. Hurley, Justice, LuCK, And KNOWledge 17, 111 (2003) (describing the regression requirement, stating that "to be responsible for something you must be responsible for its causes," thus, "[r] egressive control of X requires control of X's causes as well as of X itself"). Hurley rejects the notion that regressive control is required for moral responsibility. Id. at 80-105.

18. See WOLF, supra note 16, at 10 (describing, but not endorsing, the view that "there is a requirement that the agent's control be ultimate-her will must be determined by her self, and her self must not, in turn, be determined by anything external to itself'). Paul Russell refers to the "capacity for ultimate control." Paul Russell, Pessimists, Pollyannas, and the New Compatibilism, in THE OXFORD HANDBOOK OF FREE WILL, supra note 11, at 229, 248.

19. Michael Louis Corrado, Responsibility and Control, 34 HofSTRA L. REV. 59, 78 n.83 (2005); see also Corrado, supra note 3, at 1192 ("Actions are not voluntary unless they are up to the actor, and actions that are caused by prior condition are not up to the actor.").

20. See Pereboom, supra note 3 , at 246.

21. See McKenna, supra note 3, at 41-48 (describing and refining transfer-style arguments).

22. Martha Klein, Determinism, Blameworthiness, and Deprivation 50 (1990); see also Corrado, supra note 11, at 915 (using similar formulation); Corrado, supra note 3, at 1201, 1225 (same). 
[he was] not responsible should be the source of "his conduct.",23 Another approach is to crystallize the intuition through a "manipulation" argument, which first reminds us that we would not hold a person responsible if he were a puppet to a nefarious hypnotist or a demonic neurosurgeon, and then uses a series of incrementally evolving analogies to show that there are no morally significant differences between such a cleverly manipulated actor and an actor whose conduct is dictated by other forces beyond his control. ${ }^{24}$ Criminal theorists also sometimes say that this intuition is at work in the way we respond to "explanations" of bad acts: they point out that the more thoroughly we can explain a bad act, the less likely we are to blame the bad actor, and they trace this dynamic to implicit embrace of the origination requirement. ${ }^{25}$

However expressed or evoked, the intuition that a person is not responsible for acts he did not originate is widespread and common. Perhaps for this reason, originationism has been extensively defended in the academic philosophical debate about responsibility, where it is associated with two traditional views of responsibility-libertarianism and "hard determinism" - and with the intuition that attributions of responsibility should not turn on "moral luck." Even the criminal theorists who most ardently criticize originationism commonly concede that, in our lay-lives, most of us seem to be originationists. ${ }^{26}$

23. KLEIN, supra note 22, at 51; Robert Kane: Reflections on Free Will, Determinism and Indeterminism, http://www.ucl.ac.uk/ uctytho/dfwVariousKane.html (last visited Jan. 18, 2007).

24. Pereboom employs this approach to powerful effect. See PereBoom, supra note 3, at 1-36 (discussing alternative possibilities and causal histories). The characterization of the approach offered here is from McKenna, supra note 3, at 38-40, which discusses the Free Will Condition and thr Principle of Alternative Possibilities.

25. See Michael S. Moore, Causation and the Excuses, 73 CAL. L. Rev. 1091, 1092 (1985) ("Common sense often adopts ... the French proverb, 'tout comprendre c'est tout pardonner.' This common sense urges that we should excuse whenever we come to know the causes of behavior ... ."); see also Watson, supra note 3, at 275-76 (suggesting that particularistic knowledge of an accused's life may stir excusing impulses). Watson, who is not a criminal theorist, describes this phenomenon, but does not believe that explanations of bad acts are always sufficient to inspire complete excuses. Id. at 275.

26. See Moore, supra note 25, at 1091 (describing "common sense" impulses to excuse where the "causes of behavior" are known); Stephen J. Morse, Excusing and the New Excuse Defenses: A Legal and Conceptual Review, 23 CRIME \& JUST. 329, 345, 347 (1998) ("Many people also seem to believe that 'real' responsibility is impossible unless people have freedom in the strongest sense. Unless, that is, people have genuine 'contracausal' freedom, are 'prime movers unmoved,' and the like ... they cannot be 'really' responsible. ... The incompatibilist intuition that motivates critics of responsibility exerts a powerful hold on us, a hold that I am prey to and worries me."). Compatibilist philosophers make similar points. See WALLACE, supra note 13, at 58 (discussing "the persistence of incompatibilist elements in our thinking about moral responsibility," and noting that "[s]tudents . . . are quite easily led to the conclusion that it would not be justifiable to hold people morally responsible for what they do if determinism were true"); $i d$. at 222 (discussing the "widespread tendency to think about responsibility in incompatibilist terms," and observing that "students are frequently drawn to incompatibilism as a kind of default position and tend to view 
Some criminal theorists say we have an originationist criminal law. ${ }^{27}$ According to this ostensibly descriptive claim, our criminal law considers it unjust and inappropriate to affix blame or inflict punishment on actors when their acts are caused by forces beyond their control. ${ }^{28}$ Proponents of this view point to various features of the criminal law that appear to reflect an originationist approach. For example, it is sometimes argued that some or all of the criminal law's excuses reflect judgments that convincing causal explanations can be offered for certain kinds of recurring human conduct, and that actors ought to be excused in such cases. ${ }^{29}$ On this "causal" or "determinist" theory of the excuses, doctrines like the involuntary act doctrine, the irresistible impulse defense, duress, the (rarely codified) necessity excuse, provocation, and even self-defense (to the extent that self-defense has excuse-like features) trace certain sorts of human acts to psychological or biological act-generating mechanisms created and triggered by forces over which actors have no control. ${ }^{30}$ That is, these doctrines excuse actors for the originationist reason that acts caused by forces beyond the actor's control should be excused.

The originationist account of the criminal law has been criticized fiercely in recent years. The most common criticisms contend that the originationist account has difficulty explaining many of the criminal law's excuses, and that an originationist criminal law would be obligated to excuse every human act, which our criminal law obviously does not

compatibilist arguments with suspicion, as attempts to talk them out of something that is virtually obvious outside of the classroom"); WOLF, supra note 16, at 24 (noting the persistence of incompatibilist intuitions). So do philosophers and criminal theorists sympathetic to originationist intuitions. See Pereboom, supra note 3, at xiii (stating that "many people agree that criminals cannot be blameworthy for actions" caused by external influences); Corrado, supra note 11, at 916 (defining causal theory as having an intuitive appeal following "from a principle that many find hard to reject"); Thomas Nagel, Freedom, in FREE WILL, supra note 9, at 229, 242 ("I can no more help holding myself and others responsible in ordinary life than I can help feeling that my actions originate with me."). But see HURLEY, supra note 17, at 96 (suggesting that the "regression condition"-related to the control principle_-"is highly controversial between people because individuals may... have internally conflicting intuitions about whether responsibility must be regressive").

27. E.g., Kaye, supra note 3, at 1126.

28. Among the most common theories of criminal responsibility, choice theory most easily accommodates the originationist view. But it is also possible to imagine originationist flavors of character and attitudinal theory. See Corrado, supra note 8, at 475-82 (describing the choice theory as the "inability to do otherwise" because of external constraints, and comparing the overlap between choice and character theory).

29. See Kaye, supra note 3, at 1120-23 (discussing the "causal" theory of excuses).

30. See id. at 1126-31 (discussing the causal explanations behind criminal law defenses); Moore, supra note 25, at 1095-112 (explaining the theory of excuse and the causal theory with regard to criminal law excuses). 
do. ${ }^{31}$ Neither of these criticisms is as strong as it first appears. The first point, for example, incorrectly assumes that in an originationist criminal law, all excuses would be originationist excuses. In fact, while originationism mandates that nonoriginal acts be excused, it does not preclude excusing actors on other, nonoriginationist grounds. ${ }^{32}$ Thus, it may be that some of the criminal law's excuses have originationist explanations, while other excuses excuse for other reasons. ${ }^{33}$ The problem with the second criticism - which alleges that an originationist criminal law would excuse every human actor-is that it assumes that the law subscribes to absolute determinism, according to which every event, including every human act, is determined. It is true that if the law subscribes to absolute determinism, an originationist criminal law must excuse every human act (since no human act is genuinely original). ${ }^{34}$ But the assumption that the law subscribes to absolute determinism is debatable: it confuses what people and the criminal law "should believe" (purportedly, absolute determinism, since "partial determinism" is philosophically "unappealing" or "implausible"35) with what people actually believe. In fact, there is good reason to believe that most people, and the criminal law, actually subscribe to some sort of partial determinism. ${ }^{36}$ If this is true, then the fact that our criminal law does not excuse every human act is perfectly consistent with our having an originationist criminal law.

The originationist account of the criminal law is, then, both plausible and intuitively attractive. It gives us a criminal law that embraces the common intuition that a person should not be held responsible for acts caused by forces beyond his control, while also accepting that there may be other good grounds for excusing actors who have committed

31. Moore, supra note 25, at 1112-49.

32. Kaye, supra note 3, at 1133-35.

33. Another problem here is that proponents of this criticism generally fail to think imaginatively about causal accounts of human acts, and thus fail to see that there are plausible originationist explanations for many complex doctrines.

34. See Moore, supra note 25, at 1112 ("If one accepts determinism - the doctrine that every event, including human actions and writings, has a cause - then it is hard to see why everyone is not excused for all actions.").

35. See Kaye, supra note 3, at 1133 (summarizing the partial-determinism critique); Moore, supra note 25, at 1114-28 (criticizing partial-determinist strategies).

36. See Kaye, supra note 3, at 1135-57 (setting out reasons to believe that many people are partial determinists, notwithstanding the apparent implausibility of partial determinism). The popular view may change in the future, such that universal determinism becomes the popular view. If, despite such change, the criminal law continues to treat some actors as deserving of punishment, that will disprove the originationist account of the criminal law; but I think it quite possible that if universal determinism becomes the popular view, the criminal law will cease to treat actors as deserving of punishment. 
prohibited acts. Such a criminal law seems appealingly familiar and flexible.

\section{B. The Compatibilist Account of the Criminal Law}

Despite the intuitive appeal of the originationist account of the criminal law, contemporary criminal theory generally maintains that the criminal law rejects the origination requirement and takes a different approach to evaluating responsibility - the compatibilist approach.

Two impulses animate the compatibilist approach to responsibility. One is a distinctively modern attraction to causal explanations. Compatibilist literature persistently notes our burgeoning ability to explain physical phenomena in causal terms, infers that human acts can be explained in the same way too, and announces that our conception of responsibility must take this into account. ${ }^{37}$ The other impulse is an attraction to blame. It is a recurring theme in the seminal compatibilist works that blame is an indelible part of who we are, or how our society works. In this vein, David Hume wrote that "the mind of man is so formed by nature that, upon the appearance of certain . . . actions, it immediately feels the sentiment of approbation or blame," and asserted that "these sentiments are not to be controuled or altered by any philosophical theory or speculation whatsoever." 38 Two hundred years later, P.F. Strawson echoed Hume, declaring it "practically inconceivable" that we would give up blame (and other "reactive attitudes"), ${ }^{39}$ since our blaming practices "have common roots in our human nature and our membership of human communities," 40 and are "part of the general framework of human life, not something that can come up for review." "41 These "naturalistic"42 ideas appear again and again in compatibilist works. ${ }^{43}$ We need to blame, compatibilists often

37. See Robert Kane, The Contours of Contemporary Free Will Debates, in THE OXFORD HANDBOOK OF FREE WILL, supra note 11, at 9, 33 (“[D] evelopments . . in biology, neuroscience, psychology, psychiatry, social and behavior sciences," including discoveries in genetics, heredity, computers, and intelligent machines "have convinced many persons that more of their behavior is determined by causes unknown to them and beyond their control than previously believed.").

38. DAVID HuME, AN ENQUiRY CONCERNING HUMAN UNDERSTANDING 111-12 (1966).

39. Strawson, supra note 9 , at 81 .

40. Id. at 85 .

41. Id. at 83 .

42. Ishtiyaque Haji calls this the "naturalistic strategy." Ishtiyaque Haji, Compatibilist Views of Freedom and Responsibility, in THE OXFORD HANDBOOK OF FREE WILL, supra note 11, at 202, 206.

43. See, e.g., DENNETT, supra note 11, at 47 (approving Strawson's view that "abandoning the participant attitude is practically inconceivable"); JOHN MARTIN FISCHER \& MARK RAVIZZA, RESPONSIBILITY AND CONTROL 16-17 (1998) (invoking Strawson's naturalistic argument, 
suggest. We cannot help it, and even if determinism is true, that will not stop us. ${ }^{44}$

Compatibilism seeks to accommodate both these impulses at once, to satisfy both the attraction to causal explanation and the attraction to blame. It declares that one need not negate the other - that it is possible to give a causal explanation of a human act that points to forces beyond the actor's control while at the same time holding the human actor responsible. $^{45}$ To achieve this result, compatibilism maintains that origination is not a prerequisite for responsibility, and that we actually use other criteria for determining responsibility. ${ }^{46}$ Thus, the founders of modern compatibilism - and several influential compatibilists in the first part of the twentieth century-maintained that the "real" question is whether the actor was "free from constraint," meaning that there was no "external" impediment to him doing what he "willed" to do. ${ }^{47}$ If he was not "constrained," he was responsible, even if what he "willed" was itself

maintaining that our "commitment to moral responsibility . . . is very deep," calling our belief in moral responsibility a strong natural belief); PHILIP PETTIT, A THEORY OF FREEDOM 12 (2001) (citing Strawson, supra note 9 and WALLACE, supra note 13) ("The practice of imputing praise and blame ... is not an intellectual exercise .... It is written into some of our most basic reactions to one another .... The practice is rooted deeply in the architecture of our psychology ....").

44. Some compatibilists make more nuanced versions of this naturalist claim. For example, Wallace suggests that while the impulse to blame is not natural or inevitable, it is quite likely to play an important role in conventional human societies. WALLACE, supra note 13, at 32.

45. See Weatherford, supra note 3, at 144 (defining compatibilism as the view that "we are sometimes free and morally responsible even though all events are causally determined").

46. There are several recent and thorough summaries of the compatibilist criteria developed in the twentieth and twenty-first centuries, some of which track the emergence of these criteria historically. E.g., PEREBOOM, supra note 3, at 89-126; Kane, supra note 11, at 14-36; Michael McKenna, Compatibilism, in THE STANFORD ENCYClOPEDIA OF PhILOSOPHY (2004), http://plato.stanford.edu/archives/sum2004/entries/compatibilism.

47. Hobbes and Hume - founding fathers of modern compatibilism - articulated a test like this. See David Hume, A Treatise of Human Nature 262 (David Fate Norton \& Mary J. Norton eds. Oxford Univ. Press 2000) (1739) (distinguishing between "the liberty of spontaneity . . . that which is oppos'd to violence" and "the liberty of indifference . . . a negation of necessity and causes" (emphasis and footnotes omitted)); HuME, supra note 38, at 103 ("By liberty . . . we . . . mean a power of acting or not acting, according to the determinations of the will. . . . [T] his hypothetical liberty is universally allowed to belong to every one who is not a prisoner and in chains." (emphasis omitted)); Thomas Hobbes, Of Liberty and Necessity, in HOBBES AND BRAMHALL ON LIBERTY AND NeCESSITY 15, 38, 39 (Vere Chappell ed., Cambridge Univ. Press 1999) (1654) ("Liberty is the absence of all the impediments to action that are not contained in the nature and intrinsical quality of the agent"; "a free agent is he that can do if he will and forebear if he will . . liberty is the absence of external impediments."). So did several philosophers in the early- to mid-twentieth century. See, e.g., A. J. Ayer, Freedom and Necessity, in FREE WILL, supra note 3, at 110, 115 ("If I am constrained, I do not act freely."); R. E. Hobart, Free Will as Involving Determination and Inconceivable Without It, in FREE WILL AND DETERMINISM 63, 72-77 (Bernard Berofsky ed., 1966) ("The freedom of anyone surely always implies his possession of a power, and means the absence of any interference (whether taking the form of restraint or constraint) with his exercise of that power."); Moritz Schlick, When Is a Man Responsible?, in FrEE WILl AND DETERMINISM, supra, at 54, 59-60 ("[A] man is free if he does not act under compulsion, and he is compelled or unfree when he is hindered from without in the realization of his natural desires."). 
determined for him by forces beyond his control. More recent compatibilists - in and outside the legal academic literature-have recast the criteria for responsibility in various ways. Some look for a certain kind of "mesh" in the various features of the actor's mental economy: ${ }^{48}$ one mesh theory holds that responsibility attaches when an actor not only acted as he willed, but also desired to have the will he acted on (without regard to the origin of the second-order desire).$^{49}$ Another kind of theory holds actors responsible so long as their acts are produced by a "mechanism" (in the actor) that is "responsive to reasons" (without regard to why the mechanism responds in the way that it does). ${ }^{50}$ Still other compatibilist theories look to whether the actor has certain capacities, variously defined. To be blamed, the actor must have the capacity "to do the right thing for the right reasons . . . to act in accordance with the True and the Good"; ${ }^{51}$ or, on another variant, the actor must be capable of "reflective self-control," ability to grasp and apply "moral reasons," and the ability to control her behavior in accord with those reasons. ${ }^{53}$ Each of these approaches tries to capture what we look for in responsible actors, and each describes it in

48. Some theories, including Frankfurt's, require a "hierarchical mesh," meaning that the actor must not only desire to commit his act, but also desire to desire to commit his act. Harry G. Frankfurt, Freedom of the Will and the Concept of a Person, in FREE WILL, supra note 9, at 322, 322-36. Such theories presume that the ability to form higher order desires about our desires is what makes us moral beings or "persons." Id. Other mesh theories require different sorts of synchronicities. Gary Watson's view is that the actor's act must be consistent with his reasoned values. See Gary Watson, Free Agency, in FrEe WILL, supra note 9, at 337, 338 (examining the difference between wanting and valuing); see also Haji, supra note 42, at 210-25 (surveying the mesh theories of Harry Frankfurt, Gerald Dworkin, Gary Watson, Susan Wolf, and Hilary Bok); Kane, supra note 11, at 20 (summarizing Haji, supra note 42); McKenna, supra note 46, at 5.3 (describing Frankfurt's hierarchical mesh theory).

49. Frankfurt, supra note 48 , at 323 (we have "first-order desires" (desires to act) and "secondorder desires" (desires about which first-order desires to act on); we are morally responsible when our actions are produced by a desire to act that we desired to have).

50. Fischer and Ravizza's influential theory holds that "[a]n agent is morally responsible for performing an action insofar as the mechanism that actually issues in the action is reasonsresponsive." John Martin Fischer, Responsiveness and Moral Responsibility, in FREE WILL, supra note 3, at 214, 219; see also R.A. Duff, Who Is Responsible, for What, to Whom?, 2 OHIO ST. J. CRIM. L. 441, 444- 45 (2005) (invoking reasons-responsiveness criteria). See generally FISCHER \& RAVIZZA, supra note 43 (explaining that the actor's act must be the product of a moderately reasonsresponsive mechanism for which the actor has taken responsibility).

51. Wolf, supra note 16, at 87 . "This ability may be roughly analyzed into two narrower abilities. The first is an ability of thought, the ability to know what is in accordance with the True and the Good; the second is an ability of execution, the ability to convert one's knowledge into action." Id. at 87-88 (emphasis omitted). Provided an actor satisfies these criteria, she is responsible for her actions, even when she declines to embrace the True and the Good. Id. at 88 .

52. WALLACE, supra note 13 , at 162 .

53. Id. at $157-62$. 
a way that makes it possible for an actor to be responsible even if his act was caused by forces beyond his control.

Many criminal theorists say (or assume) that the criminal law takes the compatibilist approach, ${ }^{54}$ weaving compatibilist criteria into the familiar choice, attitude, or character theories of criminal responsibility. ${ }^{55}$ Thus, in choice theory, ${ }^{56}$ in which an actor is responsible for an act so long as she had both the capacity and a "fair opportunity" to choose to act other than she did, ${ }^{57}$ compatibilists define the relevant capacity and opportunity in ways that render "genuine" free will and origination unnecessary. All that is required for responsibility is that the actor have the ability to engage in practical reasoning and not be subject to an immediate threat to one of her socially recognized interests (such as her interest in her physical safety). ${ }^{58}$ Something similar happens in

54. E.g., George Fletcher, Rethinking Criminal LaW 800-01 (1975); Peter Arenella, Convicting the Morally Blameless: Reassessing the Relationship Between Legal and Moral Accountability, 39 U.C.L.A. L. REV. 1511, 1614 (1992); Moore, supra note 25, at 1091; Morse, supra note 26, at 332; George Vuoso, Note, Background, Responsibility, and Excuse, 96 YALE L.J. 1661,1685 (1987).

55. For overviews of these theories, common in criminal theory, see MOORE, supra note 1, at 548-93, describing choice theory and character theory, and Peter Westen, An Attitudinal Theory of Excuse in Criminal Law 39-57 (The Berkeley Elec. Press, Working Paper No. 341, 2004), available at http://law.bepress.com/expresso/eps/341, describing choice theory, character theory, and Westen's attitudinal theory.

While some compatibilist criminal theorists are choice theorists, attitudinal theorists, or character theorists, it is also possible to subscribe to these theories without being a compatibilist. For example, one may be a consequentialist choice theorist, attitudinal theorist, or character theorist. See MOORE, supra note 1, at 550 (maintaining that Hart originally gave consequentialist rationales for choice theory); $i d$. at 574 (noting that Richard Brandt and Nicola Lacey offer consequentialist character theories); Corrado, supra note 8, at 469-70 (highlighting that choice and character theories can be either retributive or utilitarian). See generally Dan M. Kahan \& Martha C. Nussbaum, Two Conceptions of Emotion in Criminal Law, 96 CoLuM. L. REv. 269 (1996) (describing their attitudeoriented theory as consistent with both consequentialist and retributive approaches to punishment).

56. MOORE, supra note 1, at 548-49 (describing and approving choice theory); Westen, supra note 55, at 45-54 (describing and rejecting choice theory). Moore characterizes choice theory as a Kantian theory, traces its contemporary forms to Hart, and characterizes leading contemporary compatibilist philosopher John Martin Fischer (whose work has influenced a number of contemporary criminal theorists) as a choice theorist. MOORE, supra note 1, at 549-50, 573 n.57. For further discussion of choice theory as a Kantian theory, see Antony Duff, Virtue, Vice, and Criminal Liability: Do We Want An Aristotelian Criminal Law?, 6 BufF. CriM. L. Rev. 147, 149-50 (2002). Westen puts Kadish in this group too. Westen, supra note 55, at 44-46 \& nn.98-102.

57. MOORE, supra note 1, at 548, 554. Westen suggests that Morse takes this approach and that Hart sometimes did. Westen, supra note 55 , at $45 \&$ n.100, 46-54.

58. See MOORE, supra note 1, at 561 ("[T] lack a fair opportunity to avoid doing wrong, there must be some (objectively regarded) evil that one is avoiding, ... . some substantial evil [such as] [1]oss of one's bodily integrity by being shot in the knees ...."); Peter Arenella, Character, Choice, and Moral Agency: The Relevance of Character to Our Moral Culpability Judgments, in CRIME, CulPaBility, AND REMEDY 59, 65 (Ellen Frankel Paul et al. eds., 1990) (“[M]ost [choice theory] accounts . . . adopt a narrow time-frame that focuses on . . the circumstances immediately preceding the criminal act...."). 
attitudinal theory, ${ }^{59}$ according to which actors are responsible if it can fairly be said that their acts reflect a reprehensible attitude toward some socially approved interest, ${ }^{60}$ and excused only if, in light of the circumstances or the actor's disabilities, it is not appropriate to infer a reprehensible attitude from the act. ${ }^{61}$ Attitudinal theorists commonly take the compatibilist view that it does not matter that the actor's attitudes did not originate with him. And things play out much the same in character theory, which says an actor is judged morally responsible for his bad act if the act can be traced to bad character in him. ${ }^{62}$ Whether they take the "Humean" approach ${ }^{63}$ or the "Aristotelian" approach, ${ }^{64}$ character theorists commonly hold the compatibilist view that an actor can be blamed for bad character even if his character was brought about by forces beyond his control. ${ }^{65}$

59. Theorists who might be called attitudinal theorists include Peter Westen, Dan Kahan, and Martha Nussbaum. See Kahan \& Nussbaum, supra note 55; Westen, supra note 55.

60. Arenella, supra note 54, at 1576-80; Westen, supra note 55, at 71.

61. Westen, supra note 55, at 71-81.

62. See MOORE, supra note 1, at 572 (citing ROBERT NOZICK, PHILOSOPHICAL EXPLANATIONS 838 (1981)) (describing character theory as the view that "we are excused ... when [our] actions do not manifest, express, reveal, or indicate bad character . . . or when such actions are not evidentiary of bad character"); Westen, supra note 55, at 39-42 (describing character theory as the view that a person is blameworthy "only if, his conduct manifests bad character . . . that is . . . only if . . . his conduct reveals him to possess a settled disposition to disregard the legitimate interests of others"). Character theory is sometimes associated with Hume, and sometimes associated with Aristotle. Moore also characterizes contemporary "mesh" theory compatibilists like Frankfurt and Watson as character theorists. MOORE, supra note 1, at 573 n.57. In criminal theory, character theorists include George Fletcher, Peter Arenella, George Vuoso, and John Gardner. See FleTCHER, supra note 54, at 800; Arenella, supra note 58, at 59-83; Arenella, supra note 54, at 1524-25; John Gardner, The Gist of Excuses, 1 BufF. CRIM. L. REV. 575, 576 (1998) ("This example shows that, sometimes, standards of character figure in the criminal law because they are built into the definitions of particular criminal offenses . . . ."); Vuoso, supra note 54, at 1685 (arguing that a person is morally responsible for the acts that reflect badly on her character).

The line between attitude and character is not always clear. A common way to distinguish them is to say that a "character trait" is "a well-established and relatively fixed set of values, attitudes, and desires," while an attitude need only be expressed on a single occasion. Arenella, supra note 54, at 1577.

63. According to the Humean approach, certain sorts of disabilities and certain difficult circumstances can disrupt the link between the actor's acts and his character, such that the actor's bad acts do not reflect his true character and are therefore not blameworthy. See Duff, supra note 56 , at $152-53$ (recounting "Humean character-based" theory and distinguishing from Aristotelian character theory); Gardner, supra note 62, at 576 (analyzing excuses under the "Humean" view).

64. The Aristotelian approach rejects the Humean idea that hard circumstances can disrupt the link between conduct and character, but excuses seemingly bad acts when circumstances are so difficult that "caving in" is consistent with normatively acceptable character. See Gardner, supra note 62, at 586-87 (articulating Aristotelian character theory). Duff includes Kahan and Nussbaum in this group. Duff, supra note 56, at $154 \mathrm{n} .10$ (citing Kahan \& Nussbaum, supra note 55).

65. See John Gardner, The Mark of Responsibility, 23 OXFORD J. LEGAL StUD. 157, 171 (2003) and Vuoso, supra note 54, at 1685 , for character theorists taking the position that an actor need not originate his character to be responsible. 
Thus, while they disagree on many important points, compatibilist criminal theorists in all three groups share the view that compatibilism does a better job of explaining the criminal law than originationism does. The excuses, for example, can be explained as expressions of compatibilist criteria: they excuse actors not because their acts were not original, but because their acts were not really chosen, or did not reflect a bad attitude, or did not spring from undesirable character; not because the actor was caused to do what he did by forces beyond his control, but because the actor lacked the capacity for practical reason, or suffered some hard circumstance. Indeed, say the compatibilist criminal theorists, many of the criminal law's various excuses cannot be explained in originationist terms; they can only be explained by compatibilist choice, attitude, or character theories.

Among criminal theorists who believe we have a retributive criminal law, this is the dominant view. Most criminal theorists say that if we have a retributive criminal law, it is also a compatibilist one.

\section{Critical Perspectives on the Compatibilist Account of the Criminal Law}

Although compatibilism is the majority view among philosophers and criminal theorists, the compatibilist account of the criminal law is vulnerable to a variety of criticisms. For example, contemporary compatibilists have not yet articulated a set of criteria for blameworthiness that can fully explain certain criminal law doctrines, such as the automatism doctrine, ${ }^{66}$ or some persisting debates in the criminal law, such as the debates about the significance of addiction for responsibility ${ }^{67}$ and the handling of sex offenders. ${ }^{68}$ Other critiques of compatibilism highlight some of its allegedly unappealing features. It is said to be unfair, because it makes blame turn on moral luck, like a lottery, and it can be seen as parasitic on pathologies in human thought, such as our well-documented tendency to overestimate the role of human actors and underestimate the contribution of circumstances when explaining human acts. ${ }^{69}$

66. Corrado, supra note 3, at 1201-09.

67. See Corrado, supra note 11, at 914 (exploring whether the compatibilist approach can "capture the notion of a choice that is resistible but very, very hard to resist").

68. See generally Corrado, supra note 19 (exploring the philosophical bases of sexual predator laws).

69. Kaye, supra note 3, at 1157-76. 
These are potentially fruitful critiques, but this Article takes a different tack. In the Parts that follow, I inquire into the politics of the compatibilist criminal law, exploring what having such a law would mean for allocations of power and resources in society. I conclude that while the compatibilist account of criminal responsibility rarely makes a show of its politics, it is in fact distinctly solicitous to the existing social and political order.

\section{COMPATIBILISM'S DISREGARD FOR HARD SOCIAL CONDITIONS}

The remainder of this Article provides an account of the politics of the compatibilist criminal law. Here, I lay the foundation for the political account by highlighting an important distinction between compatibilism and originationism: at least as it appears in contemporary criminal theory, compatibilism is less attentive to the relationship between hard social conditions and criminal responsibility.

In saying that criminal theory's compatibilism is less attentive to hard social conditions, I mean that it is less likely to consider hard social conditions like poverty, inequality, and discrimination relevant to criminal responsibility. When a compatibilist is attempting to determine whether an actor is responsible for his act, the compatibilist is less likely to explore the role that hard social conditions played in the act; if a person claims that present or past exposure to a particular social condition diminishes his responsibility for an act, the compatibilist is less likely to credit this claim. In short, the compatibilist is more likely than the originationist to sever or abstract the individual actor from his social context ${ }^{70}$ and to say that hard social conditions are beside the point.

70. As Alan Norrie has demonstrated, the same decontextualizing tendency is present in many of the criminal law's most fundamental doctrines. See Alan NorRIE, CRIME, REASON AND HISTORY: A CRITICAL INTRODUCTION TO CRIMINAL LAW 23-24 (1993) (criminal law's individualist tendencies obscure the role of social context in crime); id. at 36-46 (criminal law's focus on intention rather than motive obscures social context); $i d$. at 110-17 (voluntary act doctrine is structured to obscure role of social context in crime); id. at 187-94 (criminal law's conception of insanity obscures the role of social conditions in madness and thus madness-related crime); see also $i d$. at 171 ("[The law] is only interested in this individual performing these acts at this time. Everything else, which gives what the individual did meaning, and without which he would not have acted, is irrelevant."); $i d$. at 172 ("The law focuses its attention on an isolated homunculus, an individual without past or future, a solitary atom."). Norrie associates the criminal law's decontextualizing tendencies with its Enlightenment-style political and psychological individualism. Id. at 15-31. The criminal law's compatibilism may be rooted in similar soil.

Behavioral economists and critical realists have also noted the decontextualizing tendency in the criminal law (and in the law generally). Jon Hanson and David Yosifon, for example, draw on behavioral psychology to suggest that human cognition is calibrated to see human actors as largely independent of their contexts: well-known heuristics, systematic biases, and ingrained knowledge structures consistently channel our attention away from the circumstances surrounding human acts, 
Part III.A shows that criminal theory's compatibilism is inattentive to hard social conditions, and explains why this is likely a stubborn feature not only of contemporary compatibilism, but of compatibilism generally. Part III.B briefly contrasts compatibilism's attitude toward hard social conditions with the more flexible and receptive originationist attitude. In Part IV, I will show how the difference between these two approaches makes the compatibilist criminal law more conducive to both ideological and coercive defense of the social order.

\section{A. How Compatibilist Responsibility Inquiries Marginalize Hard Social Conditions}

In order to determine whether a person is responsible, the compatibilist (of whatever stripe) must inquire into certain factsnamely, facts about the actor's features and circumstances at the time of the act. Of course, contemporary compatibilism is so diverse that these compatibilist responsibility inquiries come in several different forms, focusing on different aspects of the actor and his situation; but, despite their diversity, compatibilist responsibility inquiries have one noteworthy feature in common - they all push hard social conditions to the margins of the responsibility determination. ${ }^{71}$

This Subpart shows why this is so. It identifies three sorts of inquiries that contemporary versions of compatibilism make in determining responsibility-which I will call feature/capacity inquiries, ownership inquiries, and evidentiary inquiries - and shows that these inquiries are largely inattentive to facts about hard social conditions. ${ }^{72}$

and focus us on the human actor alone. Legal doctrine and theory, in turn, replicate flawed human cognition. Jon Hanson \& David Yosifon, The Situational Character: A Critical Realist Perspective on the Human Animal, 93 GEO. L.J. 1, 133-38 (2004). As my argument below will suggest, I think it plausible that these cognitive biases themselves can be traced to political culture; a more conventional claim might be that individualist political culture flourishes because it exploits or capitalizes on these cognitive biases.

71. One could say they "truncate[] the inquiry into moral responsibility" by drawing the line at social conditions. R. George Wright, The Progressive Logic of Criminal Responsibility and the Circumstances of the Most Deprived, 43 CATH. U. L. REV. 459, 463 (1994); see also id. at 475-76 (suggesting social conditions are excluded artificially).

72. For example, adopting the compatibilist perspective can make us insensitive to what some authors call "constitutive moral luck"-bad luck with respect to the genetic, environmental, and experiential factors that make us who we are. See, e.g., Nir Eisikovits, Moral Luck and the Criminal Law, in LAW AND Social JustiCE 105, 117 (Joseph Keim Campbell et al. eds., 2005) ("The question of whether constitutive, circumstance, or causal luck have any important bearings on the criminal law is almost completely overlooked .... Perhaps [this] is due to the fact that both sides share a compatibilist assumption . . . . According to such a view, the first three categories do not raise serious moral problems . . . . It is possible that we would not have killed if we were more tolerant by nature, or if we had grown up in a different neighborhood . . nevertheless ... we are still 
This is so, I argue, because contemporary compatibilism is not disposed to attend to forces that influence conduct the way social conditions doprimarily by shaping actors' wants and dispositions in incremental and holistic ways. Moreover, I will argue, it cannot do so without jeopardizing one of the central projects of compatibilism.

\section{Feature/Opportunity Snapshots and Social Conditions}

Most versions of contemporary compatibilism, including most of the versions of compatibilism articulated, followed, or cited by criminal theorists, place heavy emphasis on whether the actor had certain features and certain opportunities at the time of his act. Ascertaining whether an actor has these features and opportunities requires an inquiry into a narrow set of facts - facts that can be captured by a "time-slice" "snapshot" of the actor at the time of the act itself. ${ }^{73}$ Such snapshot feature/opportunity inquiries of course tell us some important things about the actor, but they provide little opportunity to incorporate hard social conditions into the responsibility determination.

Contemporary compatibilists typically hold that actors must have various sorts of features to be morally responsible. For example, actors must have certain capacities in order to be responsible. The choice theorist will say that the actor must have the sorts of intellectual capacities necessary for meaningful acts of choice, including the ability to engage in practical reasoning. Attitudinal and character theorists often require similar capacities, on the ground that the inference from an actor's bad act to a blameworthy attitude or character trait is not justified unless the actor has capacities such as the capacity for rational thought. ${ }^{74}$ Other capacities are sometimes required as well: Arenella requires the actor be capable of empathy and moral self-revision, ${ }^{75}$ Wallace holds that

accountable.").

73. FISCHER \& RAVIZZA, supra note 43, at 185. Some such "internalist" or "time-slice" theories, hold that a person's responsibility depends entirely on the state of the actor's "mental economy" at the time of the act, $i d$., though, such theories might also approve "evidentiary" inquiries of the sort described infra Part III.A.3. But even theories that look beyond the snapshot of the actor's mental economy place heavy weight on the snapshot itself. The sense that this is a "narrow" or "limited" sort of inquiry is expressed throughout the literature. See, e.g., MoORE, supra note 1, at 577 (noting that choice theory is less interested in the "stories" behind acts than "character theory," and that choice theory "requires a more limited enquiry into [an actor's] capacities and opportunities at the moment of acting").

74. See MOORE, supra note 1, at 548 (under choice theory, a person is excused from an action because of a lack of sufficient capacity); Vuoso, supra note 54, at 1683 (an act may not reflect a person's character if they are not a rational agent).

75. Arenella, supra note 58, at 59. 
the actor must be capable of "reflective self-control,",76 and Wolf says she must be capable of recognizing "the True and the Good." 77 Sometimes, the feature at issue is not a capacity, but a mechanismFischer and Ravizza hold that the actor is only responsible if his act is the product of a "reasons-responsive mechanism" in the actor. ${ }^{78}$ And sometimes the required feature is a mesh - the actor's desires, wants, wills, or attitudes must "mesh" in a certain way if we are to hold him responsible. $^{79}$ On each sort of theory, responsibility turns in part on whether the actor had the requisite feature-capacity, mechanism, or mesh - at the time of the act.

Often, the feature requirement is paired with an opportunity requirement: in order to be responsible, the actor must have not only the right features, but also an adequate opportunity to act appropriately. After all, the capacity for practical reasoning does not mean much when there is a gun to the actor's head. It is "not fair" to hold such an actor responsible for his choices; ${ }^{80}$ or his act does not genuinely reflect his character, ${ }^{81}$ or the character revealed by the act is not an unacceptable one, given the circumstances; $;{ }^{82}$ or the act does not reflect an undesirable sentiment or attitude. ${ }^{83}$ As a result, an actor is not blameworthy if, at the time of the act, he was subject to coercion or a "hard choice." ${ }^{\text {" }}$ He must have had an adequate opportunity to act appropriately.

These feature/opportunity inquiries capture a wealth of morally significant data about the actor and his circumstances, but they provide little opportunity to incorporate hard social conditions into the responsibility determination. The feature prong of the feature/opportunity inquiry, for example, focuses entirely on the state of a person's mental economy or the extent of his cognitive capacities at the time of his act. If the requisite psychic feature - capacity, mechanism, or mesh - is present, the actor is responsible, and this prong of the inquiry ends. If the requisite feature is not present, the actor is not responsible, and-again - this prong of the inquiry ends. Either way, social conditions are beside the point. Once it is known whether the actor has

\footnotetext{
76. WALLACE, supra note 13, at 157.

77. WOLF, supra note 16, at 117.

78. FISCHER \& RAVIZZA, supra note 43 , at 46.

79. Harry G. Frankfurt, Alternate Possibilities and Moral Responsibility, in FrEE WILL, supra note 9, 167, 176; Gary Watson, Introduction to FREE WILL, supra note 9, at 1,8.

80. Morse, supra note 26 , at 341 .

81. FLETCHER, supra note 54, at 496-97.

82. Gardner, supra note 62 , at 575.

83. WALLACE, supra note 13 , at 125 ; Westen, supra note 55 , at 67-68.

84. Morse, supra note 26 , at 342 .
} 
the requisite feature, the presence or absence of a particular social condition at the time of the act will not change the result of the feature inquiry. ${ }^{85}$ Thus, while social conditions can have a formative influence on mental economy and cognitive capacity, it is the resultant psychic features, not the formative social conditions, that matter in the feature prong of the feature/opportunity inquiry. ${ }^{86}$

It is nearly the same with the opportunity prong of the feature/opportunity inquiry: generally speaking, social conditions make no difference to this inquiry. Calibrated to capture our intuitions about a rare and distinctive sort of case - the gun-to-the-head case (and its siblings), where a person engages in highly anomalous (for them) conduct in reaction to immediate, intense, and transitory pressure - the opportunity inquiry is not interested in the sort of longitudinally measured "opportunities" we refer to when we talk of opportunities for education, employment, or personal development. ${ }^{87}$ Instead, it focuses entirely on the circumstances present at about the time of the act. ${ }^{88}$ What was physically possible for the actor at that time? Was the actor facing an imminent and intense threat at the time of the act? Was the threat "unfair," in that the actor could only avoid harm to a socially recognized interest by harming another socially recognized interest? So long as the actor was not physically constrained (e.g., by chains or walls) and was not subject to an imminent, intense, and unfair threat at the time of the act, he had the requisite fair opportunity to act appropriately. ${ }^{89}$

Even very hard social conditions generally do not operate as actual physical constraints, like chains and walls. Moreover, they almost never present the sort of immediate, intense, transitory, and unfair, "gun-to-thehead" threat that deprives a person of a fair opportunity. ${ }^{90}$ It is true that

85. Sometimes the presence of a particular social condition is the best evidence we have regarding the presence or absence of a particular psychic feature. Desert inquiries that proceed in this fashion I call "evidentiary inquiries." Such inquiries are discussed below.

86. This is what criminal theorists mean when they say "one's past is irrelevant to the assessment of his moral responsibility for a wrong." Vuoso, supra note 54, at 1680. "The sort of character a person has is relevant to assessing his moral responsibility, but not how he came to have that character." Id. at 1681; see also FISCHER \& RAVIZZA, supra note 43, at 185-87 (characterizing Vuoso as a "snapshot," "ahistorical" compatibilist); MOORE, supra note 1, at 525-26 (so long as a person's desires and beliefs do not make it "difficult for him to reason practically," the fact that "what a person desires, believes, or intends is caused by his environment" is irrelevant to desert); Stephen J. Morse, Culpability and Control, 142 U. PA. L. REV. 1587, 1659 (1994) ("The law's concern is not why glitches occur. Rather, to evaluate responsibility the law needs to know only whether and to what degree glitches do occur.").

87. Arenella, supra note 58 , at 65 .

88. Id.

89. Id.

90. Morse, supra note 2, at 142. 
if social conditions are such that a person literally must choose between starving to death and stealing food, this might infringe "opportunity" in the way the compatibilists mean, rendering the actor blameless. ${ }^{91}$ But such outrageous social conditions are also almost unheard of in modern Western society; as one compatibilist criminal theorist puts it, "minimal welfare and medical care is available to virtually anyone in the United States." The hard social conditions that we actually have may cause depression, anguish, resentment, and anger-but they almost never present actors with an immediate, zero-sum choice between evils. As a result, the opportunity inquiry will be only superficially interested in hard social conditions; it will mandate inquiry into only the most outrageous and unlikely ones. ${ }^{93}$

\section{Ownership Inquiries and Hard Social Conditions}

The feature/opportunity inquiry is not the only inquiry in the compatibilist's arsenal. Many compatibilist criminal theorists recognize that "whether an agent is morally responsible cannot be read off his snapshot properties," "94 and that some sort of "historical" inquiry is necessary. ${ }^{95}$ Of course, the historical inquiry cannot be an inquiry into the ultimate causes of the actor's act - that would be originationism. Instead, compatibilists of this sort inquire into historical matters deemed important to responsibility for reasons having nothing to do with causation. In particular, they focus on what is sometimes called "ownership": they ask whether the actor has taken ownership of, adopted, endorsed, ratified, or taken responsibility for certain features of himself that are involved in his act. ${ }^{96}$ Such ownership inquiries can incorporate more information about the actor and his act than feature/opportunity snapshot inquiries can, but even these more flexible

91. Id.; Vuoso, supra note 54, at 1684-85.

92. Morse, supra note 2, at 142 .

93. Compatibilists may want to argue that this makes sense, perhaps on the ground that since most people are responsible most of the time, exposure to common social conditions should not be an excuse. For the moment, however, that is beside the point. All I seek to show in this Part is that social conditions are rarely incorporated into this sort of compatibilist inquiry.

94. See FISCHER \& RAVIZZA, supra note 43, at 187 ("[E]xhibiting the current time-slice features constitutive of responsibility is consistent with . . . having the sort of history that, arguably, rules out moral responsibility [such as a history of] physical abuse as a child.").

95. See Watson, supra note 3, at 256-86 (discussing the "relevance of such historical considerations").

96. See Arenella, supra note 58, at 65 (suggesting that actors are only responsible for acts that flow from character traits they could have revised). 
inquiries still fail to incorporate information about social conditions to any meaningful degree.

There are various sorts of ownership inquiries, and it sometimes appears that they place emphasis on ownership of different sorts of features. Some compatibilists focus on ownership of the particular desires, attitudes, or dispositions that generate the actor's act: they say that for an actor to be responsible for an act, he must have taken ownership of the desires, attitudes, or dispositions that gave rise to his act. Of course, they cannot hold that ownership requires that the relevant desires, attitudes, or dispositions originate with the actor-for that would appear to be the originationist's position, which the compatibilist rejects. To avoid the origination requirement, some theories hold that it is enough that a desire, attitude, or disposition fits harmoniously into the greater scheme of one's desires, attitudes, or dispositions, or (to put it another way) that the actor "identifies" with the desire, attitude, or disposition. ${ }^{97}$ This ownership-as-identification approach entails only a time-slice feature question; all it asks is whether there was the right sort of harmony between the desires, attitudes, or dispositions the actor acted on, and the rest of his desires, attitudes, or dispositions at the time he acted.

The genuinely historical approach requires more than that: it holds that in order to take ownership of a desire, attitude, or disposition, an actor must traverse a certain process. The simplest version seems to hold that ownership can arise when an actor sustains a desire, attitude, or disposition for a certain period of time. In this vein, one theorist says that if a "bump on the head" turns a kind person into a cruel one, we might feel inclined to excuse the actor for cruel acts committed shortly thereafter, but if the change "persists long enough," this "shift[s] our sense of the agent," and it becomes appropriate to blame her for resulting bad acts. ${ }^{98}$ There is a similar account of brainwashing, which may not be an excuse unless the brainwashed person "had not had adequate time between the conditioning and the criminal act in which to reject or integrate her new beliefs into her character."

97. Frankfurt, supra note 79, at 167-76.

98. See HuRley, supra note 17 , at 47-48 (drawing on T. M. SCANLON, What We OwE To EACH OTHER 279 (1998)). Hurley holds that the crucial question is whether the actor has taken ownership of the character trait (however the character trait came about), but suggests that as time passes it becomes increasingly appropriate to conclude that ownership has been taken, unless actively foresworn. Id. at 47-48.

99. MOORE, supra note 1, at 533-34. Moore suggests this view while describing a version of character theory. Though Moore rejects character theory, it is not clear that he rejects this account of brainwashing, which he generally denies excuse status. 
such theories appear to require that the responsible person actively approve his beliefs/desires, or at least fail to reject them despite having the capacity to do so. ${ }^{100}$ In such theories, it is the process of incorporation, not just the resulting harmony, that makes for ownership.

Other compatibilists focus on ownership of more complex featuresnot just the actors' attitudes, but the "mechanisms" in actors that generate their acts, the machinery that processes desires and attitudes and determines whether they will be acted upon. According to Fischer and Ravizza, for example, an actor is only responsible for an act if it is the product of a "reasons-responsive mechanism" that the actor has "acquired" or taken "ownership" of. ${ }^{101}$ The reasons-responsive mechanism is the feature that makes the actor responsible, but it is not enough that the actor have this feature - the actor must also have taken ownership of it. For Fischer and Ravizza, taking ownership can only be accomplished through a particular process: an actor takes "ownership" of his "mechanism" when he (1) comes to see himself as a genuine agent, (2) comes to see himself as an apt target for the reactive attitudes of those around him, and (3) arrives at these conclusions on the basis of good evidence. ${ }^{102}$ Thus, again, a time-slice inquiry is not enough. A historical inquiry is necessary to determine whether the process that amounts to taking ownership has occurred.

Both sorts of ownership inquiries are considerably more flexible than time-slice inquiries, for they authorize the inquirer to step out of the snapshot and into the past. Still, even these more flexible inquiries have little capacity to meaningfully incorporate hard social conditions in the responsibility determination. For example, if all that is required for a person to take ownership of an attitude is that the person have the attitude for a certain period of time without disclaiming it, the inquiry will be focused entirely on how long the attitude existed, and whether the

\footnotetext{
100. Arenella, supra note 58, at 76 .

101. See FISCHER \& RAVIZZA, supra note 43, at 230 ("What seems relevant is not only the fact that the mechanism issuing in the action is suitably reasons-responsive; what also matters is how that mechanism has been put in place."). In this light, an inquiry limited to mere reason-responsiveness "does not make us look sufficiently far into the past"; we must also look at the "process of taking" ownership. Id. at 230-31.

102. Id. at 210-14. To see oneself as a genuine agent is to believe that one's "choices and actions are efficacious in the world." Id. at 210. To see oneself as an apt target of others' reactive attitudes is to see it as "fair," given the social context, for others to subject one to their reactive attitudes, $i d$. at 211 , at least in the limited sense that one sees oneself as a participant in the moral community, $i d$. at 213. To arrive at these conclusions on the basis of good evidence is to see oneself as an agent on the basis of legitimate evidence that one's acts are efficacious, and to see oneself as an apt target for reactive attitudes on the basis of legitimate evidence that "social practices" generally make people like oneself targets of reactive attitudes. Id. at 213.
} 
actor resisted it. This is a question of what the actor did, and in what time frame. Social conditions are irrelevant here: the presence or absence of a particular social condition will not change the fact that time passed or did not, nor will it change the fact that the actor resisted or failed to resist an attitude. Though social conditions may have brought an attitude to life and dictated the actor's treatment of the attitude, the attitude-ownership inquiry is not concerned with where an attitude came from nor why the actor treated it the way he did. It is only concerned with how the actor treated the attitude once it arrived.

The same is true of the more complex mechanism-ownership inquiries. For example, while Fischer and Ravizza do devote some attention to the role social conditions play in conduct, and express sympathy for the notion that social conditions might sometimes be excusing, their mechanism-ownership inquiry leaves little room for accommodating these intuitions. Whether an actor has a reasonsresponsive mechanism is, itself, a time-slice question, for which social conditions are beside the point. Whether the actor owns his mechanism is a historical question, and thus opens the door to a historical inquiry; but this historical inquiry is structured in such a way that there is little room for meaningful inquiry into hard social conditions.

Notice, for example, that hard social conditions are totally irrelevant to the first two facets of the mechanism-ownership inquiry. An actor either does or does not come to see himself as a genuine agent and an apt target for reactive attitudes - this is entirely a matter of what happens in his psychic economy. One might imagine that social conditions could have a bearing on the third process factor, whether the actor comes to see himself as a genuine agent and apt target for reactive attitudes on the basis of good evidence. For example, it is conceivable that an actor could be "tricked" into seeing himself in these ways by his political culture's misleading accounts of agency or reactive attitude. In such a case, he would reach the developmental landmarks necessary for responsibility, but do so on the basis of "bad evidence" (namely, misleading cultural accounts of agency and reactive attitude). But opening the door to this possibility does not mean opening the door to a significant inquiry into social conditions. For one thing, cases like this surely are exceedingly rare. It will almost never happen that social conditions will trick a person into seeing himself as an agent, or into believing he is the sort of person that social practice identifies as an apt target for reactive attitudes. Nearly all people in modern Western society, no matter what their social environment, will reach these conclusions on the basis of mundane, elemental observations about the efficaciousness of their acts and the reactive practices of their society. 
More to the point, even if this inquiry can be said to pay heed to social conditions, the conditions it pays heed to are far from the heartland of conditions that seem most likely to be bound up with human acts. There is no room, here, to consider the way social conditions influence the actor's attitudes, no room to account for the ways social conditions influence conduct through their influence on our desires, attitudes, and dispositions. Thus, though Fischer and Ravizza note the possible significance of social conditions like deprivation and inequality, their mechanism-ownership inquiry makes little room for a meaningful inquiry into the relationship between these conditions and human acts.

Indeed, upon reflection, it should not be surprising to discover that ownership inquiries are largely incapable of accommodating inquiry into social conditions, for social conditions are largely irrelevant to the sort of ownership at issue here. Generally speaking, social conditions do not make us act on attitudes or mechanisms we do not "own," as though social conditions were a computer hacker installing a malicious and anomalous code; rather, social conditions instill such attitudes and mechanisms as part of the larger, incremental and holistic process of shaping our unified identities. The ownership criteria has been developed with the hacker-type case in mind. In fact, it has been designed to capture our moral intuitions about a highly stylized sort of hypothetical popular in the philosophical literature-one in which an omnipotent and nefarious actor (a demon, a superneurosurgeon, or a diabolical hypnotist) implants a desire in an actor, and the desire causes the actor to commit a particular act. ${ }^{103}$ Most of us share the intuition that such actors are not responsible, but feature/opportunity analysis has trouble explaining why. The ownership requirement provides an easy answer: the actor is not responsible because he does not own the desire implanted by the nefarious demon, doctor, or hypnotist. In the real world, of course, our desires almost never arise this way. We are rarely "hacked." More to the point, it is especially unlikely that social conditions "hack" us. Thus, the ownership inquiry will almost never turn to social conditions - it has its eyes out for demons, superneurosurgeons, and hypnotist hackers, not poverty and inequality.

103. See, e.g., id. at 236 (explaining the mechanism-ownership criteria as a response to hackerstyle cases). 


\section{Evidentiary Inquiries and Social Conditions}

There is another way the contemporary compatibilist can arrive at a more expansive responsibility inquiry: facts that are considered formally irrelevant to responsibility might still be deemed useful on evidentiary grounds, insofar as they can cast light on whether a formally relevant fact is true. ${ }^{104}$ The inquiry into such evidentiary facts is likely to sweep more broadly than the feature/opportunity and ownership inquiries. For our purposes, however, compatibilist evidentiary inquiries play out the same way that feature/opportunity and ownership inquiries do: they pay little heed to hard social conditions.

The premise of the evidentiary inquiry is that even facts that are not formally determinative of responsibility can sometimes be the best available evidence regarding facts that are determinative of responsibility. This is so because we are not very good at determining whether feature or ownership criteria are satisfied in particular cases. We cannot always directly perceive whether a person has features like the capacity for rational thought or the capacity to recognize "the True and the Good"; nor are we likely to have direct evidence about whether the actor owns his attitudes or his reasons-responsive mechanisms. In some cases, however, we can at least partly overcome these epistemic problems by asking whether a person with this actor's past is likely to have the requisite features, or to satisfy the ownership requirement. ${ }^{105}$ For example, we might think that a person with a particular history is especially likely to lack the capacity for rational thought, or especially likely to lack the capacity to recognize "the True and the Good." 106 And

104. See, e.g., Watson, supra note 3, at 263-65 (discussing possibility that information about deprived childhood is mitigating because it is indirect evidence that the actor suffers from a present disability). There are hints of this evidential use of historical facts about acts throughout the literature of compatibilism. See, e.g., Morse, supra note 86, at 1659 ("Understanding the causal background may in some cases be probative about whether an excusing condition exists," even when "no particular cause is required to justify the excusing condition."); Vuoso, supra note 54, at 1681 ("His past might be relevant in helping us to understand the nature of the defects in his character.").

105. See, e.g., FISCHER \& RAVIZZA, supra note 43, at 188-90, 195 (describing "epistemic" inquiries); WALLACE, supra note 13, at 165 (noting that it is "not . . . always entirely clear which people actually have the powers of reflective self-control" and observing a correlation between the presence of this feature and "certain sorts of moral education . . . and emotional support . . . and freedom from hypocrisy and arbitrariness in the promulgation and enforcement of moral standards"); id. at 233 n.8 ("[A]ppeals to childhood deprivation affect our judgments of responsibility by altering our perception of the motives and abilities of the wrongdoer as an adult ... ."); WOLF, supra note 16, at 85-86 (discussing blameworthiness and the "Reason View").

106. See Wolf, supra note 16, at 86 (conceding that it is difficult to know whether a person has the capacity to recognize and conform to the True and the Good, and explaining that it helps to consider whether "persons with a similar history" have or lack the relevant traits). 
the same approach can be applied to address questions of ownership. Again, we might think that a person with a particular history might be especially likely to own (or fail to own) his attitudes or his reasonsresponsive mechanism.

This sort of inquiry lends itself to a much more creative and inquisitive review of the history of an act than the time-slice and ownership inquiries described so far. So long as we think that a particular event or circumstance might be correlated with whether an actor has the features or ownership necessary for responsibility, we are authorized - or obligated - to scan the actor's history for that event or occurrence. Indeed, many compatibilists explicitly or implicitly attempt to use this approach to make their compatibilisms sensitive to social conditions.

Susan Wolf does this in a thoughtful way. Wolf's criteria for blame looks to whether the actor is able to "do the right thing for the right reasons." 107 The test is whether the actor has "the ability to know ... the True and the Good," and the "ability to convert [that] knowledge into action." 108 Of course, Wolf says, it can be difficult to ascertain whether an actor has these features directly, so it is sometimes useful to scan the actor's history for influences likely to foster or impair the development of these abilities. ${ }^{109}$ According to Wolf, this evidentiary inquiry will be attentive to social conditions, for some social conditions-like childhood deprivation and pathological moral education - have predictable impacts on whether actors develop the abilities necessary for responsibility. ${ }^{110}$

The problem is that this evidentiary inquiry makes less room for attention to hard social conditions than Wolf appears to think. For one thing, the door to this evidentiary inquiry does not even open unless there is doubt about ownership or the actor's features, in the first place. For example, if having the capacity to recognize and act upon "the True and the Good" makes an actor responsible (as Wolf says it does), and if it is reasonably clear that the actor does have such a capacity, it will not be appropriate to embark on any more free-wheeling evidentiary exploration. Thus, in many cases there will be no call for this sort of historical inquiry and it will take us nowhere toward contemplation of social conditions.

\footnotetext{
107. Id. at 87 .

108. Id. at 87-88; see also id. at 143 (clarifying that the capacity to know the True and the Good entails the ability to "appreciat[e] that it was wrong, and that something else would have been

109. Id. at 86 .

110. Id.
} better"). 
Moreover, even when this sort of inquiry is appropriate, it will only crack the door to consideration of social conditions. Even at its broadest, the inquiry can only look to facts that bear on the presence of the requisite features and ownership, but most social conditions, even the ones we commonly associate with antisocial conduct, simply have no bearing on either the presence or absence of such features or ownership. Consider Wolf's example again: Wolf suggests that when social conditions dictate a person's values, this can dissolve moral responsibility. ${ }^{111}$ It is not clear, however, that on her standard for moral responsibility this is a meaningful possibility. She suggests that certain social conditions are likely to prevent or substantially impair the development of the capacities required for moral responsibility-the capacities to recognize and act in conformity with "the True and the Good." "12 But, upon reflection, it seems implausible that the most common of the social conditions she discusses could have this effect. For example, she suggests that childhood deprivation could have this effect; but it seems implausible that any realistically imaginable state of childhood deprivation would actually prevent an actor from developing the ability to recognize "the True and the Good" "113 or that it would really eviscerate the ability to act in accord with "the True and the Good." At least in contemporary Western society, our conceptions of "the True and the Good" are transmitted so persistently and pervasively, and through such a diversity of media, that it does not seem possible that an intellectually intact person could reach adulthood without being able to recognize "the True and the Good." "And while childhood deprivation

111. In fact, Wolf sometimes wavers on this claim, characterizing it as "controversial." Id. at 37.

112. See id. (describing the persons as having "values we are apt to explain as resulting from deprived or otherwise traumatic childhoods").

113. The ability to "recognize" moral values can be defined in less and more demanding ways. But even on a more demanding definition-e.g., recognition requires not just intellectual understanding, but affective appreciation - the point holds true. This point is further developed in the discussion of R. Jay Wallace's approach to evidentiary inquiry. See infra notes 117-25 and accompanying text (discussing Wallace's approach).

114. Wolf sketches the possibility that this can happen, suggesting that social conditions sometimes deprive people of information about "the True and the Good." As she puts it, "[a] victim of a deprived (or depraved) childhood" may be "exposed to an unfortuitous collection of data" such that she cannot reason out "the True and the Good." WOLF, supra note 16, at 75-76. Given the pervasive dissemination of cultural norms in modern Western society, this seems very unlikely.

$[\mathrm{P}]$ eople raised in a culture of deprivation in the United States typically . . . know a great deal about the dominant culture and laws through schooling, the media, and other means of transmitting such knowledge .... [M]ost parents in subcultures of deprivation teach their children the "dominant" morality .... As an empirical matter, virtually all deprived people know the "dominant" moral and legal rules and possess the general capacity to understand their moral and practical bases.

Morse, supra note 2, at 147. 
might well make an actor prefer not to act in accord with "the True and the Good," it surely does not actually negate the ability to do so in anything but the most outlandish cases ${ }^{115}$-indeed, even the very worst actors, exposed to the very worst sorts of social conditions, generally act in accord with "the True and the Good" most of the time. Thus, only the most unusual social conditions - conditions that do catastrophic damage to basic human abilities - will be of any interest to Wolf's evidentiary inquiry.

Similar things can be said about the other compatibilists who endorse such evidentiary inquiries. Consider, for example, the approach recommended by R. Jay Wallace, the contemporary philosopher most often relied upon by compatibilist criminal theorists. Wallace also offers one of the most ambitious attempts to make room for social conditions in the compatibilist desert inquiry, and one of the most illuminating failures. ${ }^{116}$

According to Wallace, a person is responsible for a breach of a moral obligation if the person is capable of "reflective self-control," meaning he is capable of understanding moral reasons and capable of controlling his acts in accord with those reasons. ${ }^{117}$ Wallace maintains that certain social conditions can influence whether a person develops the capacity for reflective self-control. ${ }^{118}$ As he explains, some formative conditions, including some social conditions, are

exceptionally unfavorable to the development of a normal level of the powers of reflective self-control. People exposed to these conditions will often find it extremely difficult to take moral requirements seriously . . . . They may be subject to a kind of pent-up, displaced anger ... and this may be a source of unusually strong incentives to antisocial behavior. Or their self-esteem may be so low that ... they

Some criminal theorists offer some support for Wolf's view. See, e.g., Delgado, supra note 11, at 30-32 (arguing that underground economies with their own sets of norms arise in some circumstances, and that young people raised in such economies may not be exposed to mainstream norms); Wright, supra note 71, at 473 ("Oppressed groups may, for example, lack without culpability relevant knowledge of what the law requires. Their lack of knowledge may be the result of governmental and societal failure ...."). But even these theorists recognize that such cases "should not arise often," noting that "[m]ass communications and compulsory schooling are counteracting influences." Delgado, supra note 11, at 88 n.505.

115. Perhaps one can imagine extraordinary cases in which it does so, as by making an actor susceptible to irresistible impulses (e.g., impulses arising from literally overwhelming rage). But such conditions are either nonexistent or exceedingly rare, and Wolf does not suggest that this is the sort of social condition she is attempting to accommodate with her theory.

116. Peter Arenella's "thick" character theory has some of the same virtues and flaws. See generally Arenella, supra note 54, for Arenella's character theory.

117. WALLACE, supra note 13 , at 7.

118. Id. at 232-33. 
can ... be driven to engage in behavior that confirms their sense of failure and worthlessness.

This is a nuanced account of how certain formative conditions might lead to conduct, one that recognizes that the most basic way that such conditions influence conduct is that they generate and influence the desires, attitudes, and dispositions that drive conduct. Moreover, this account makes a compelling claim about how this process bears directly on moral responsibility. Sometimes, social conditions generate desires, attitudes, and dispositions that are antagonistic to the capacity for reflective self-control, either because they impair the ability to understand moral reasons (particularly by undermining affective understanding rather than intellectual understanding) or because they undercut the ability to conform acts to moral reasons.

So far, it might seem that Wallace's responsibility inquiry will naturally entail a significant evidentiary inquiry into the social conditions behind an actor's act, but this impression is misleading. For, as with Wolf, it is actually quite implausible that any but the most extraordinary social conditions could have the sort of impact that Wallace describes. After all, it cannot be that conditions that merely make someone dislike moral requirements are enough to defeat responsibility. Nor can it be that conditions that merely instill anger or self-doubt are good enough, for such attitudes and feelings generally do not genuinely corrupt the capacity for reflective self-control. Indeed, Wallace himself makes this perfectly clear. The conditions that defeat responsibility, he says, are ones so "chronic and extreme" "psychopath." 121 Such conditions are, realistically, hard to conceive. As Wallace points out, conditions of "desperate poverty and violence" do not rise to this level. Being raised in such conditions may make it more difficult for a person to exercise reflective self-control, but it does not "deprive[] [him] altogether of [this] power[]." ${ }^{122}$ That people experience such conditions, then, does not mean we must exempt them from blame, and it is still appropriate "to punish them for their crimes." 123 Thus,

119. Id.; see also id. at 214 (discussing how deprivations suffered as a child may affect the moral accountability of that person as an adult).

120. Id. at 232 .

121. Id. at 233. On the well-known debate whether psychopathy itself should be excusing, see Arenella, supra note 54, at 1608-21, highlighting law's reluctance to treat psychopathy as excusing and offering a character-based argument that it should.

122. WALLACE, supra note 13, at 233; see also Arenella, supra note 54, at 1615 (emphasizing rarity of cases of true psychopathy).

123. WALLACE, supra note 13, at 233. 
despite Wallace's apparent sensitivity to hard social conditions, his theory attends only to the most extraordinary ones. He recognizes that "pockets of desperate poverty and violence" are "increasingly common in modern industrialized societies," room for them in his calculation of criminal responsibility. Again, the social conditions most likely to be implicated in bread-and-butter cases of bad conduct are pushed to the margin. ${ }^{125}$

In short, even the seemingly free-wheeling evidentiary inquiry is not well-suited to incorporate social conditions into the compatibilist's responsibility inquiry. ${ }^{126}$ For one thing, the evidentiary inquiry is not available unless there is doubt about a feature or ownership - and it will often be true that there is no reasonable basis for doubt on either front. For another, the evidentiary inquiry is tethered to features in the actor that themselves are unlikely to be significantly influenced by modern Western society's bread-and-butter hard social conditions, thus making it unlikely that we will actually stray into contemplation of social conditions while we pursue this kind of evidentiary inquiry in contemporary cases. ${ }^{127}$

124. Id.

125. Wallace does emphasize that we should be willing to adjust our "moral responses" to cases in which conditions like poverty and violence exist. Id. Responsibility comes in degrees, he says, and such conditions may reduce the degree of an actor's responsibility. Id. at 234. Nevertheless, he does not anticipate that adjusting our moral responses in this way will affect our judgments of criminal desert - only conditions of the sort that bring about near-psychopathy can do that. Id. at 233. Thus, engaging in Wallace's desert inquiry in the criminal justice context will generally not lead to direct contemplation of social conditions.

126. Here I have used the accounts given by Wolf and Wallace as illustrative examples. The result would likely be the same with the other compatibilists who recognize the value of evidentiary inquiry. Consider Fischer and Ravizza, who hold actors responsible for acts produced by reasonsresponsive mechanisms they own. Fischer and Ravizza recognize that historical inquiry might sometimes cast light on whether an actor meets these requirements; but social conditions will generally be beyond the bounds of such inquiry. Only the most rare and outrageous social conditions (e.g., childhood deprivation intense enough to bring about psychopathy, or mass brainwashing in the style of 1984) could genuinely call into question whether the actor acted through a reasons-responsive mechanism, or whether he had taken ownership of that mechanism in the proper way. In most cases, it will be easily determined that such conditions were not present, and the historical inquiry will ignore the less dramatic, holistic, desire-shaping effect of much more common social conditions (like poverty and inequality).

127. See Arenella, supra note 58, at 65 (noting that nearly all adult actors, no matter what conditions they encounter, have capacity for practical reasoning and opportunity to act appropriately); Wright, supra note 71, at 476, $476 \mathrm{n} .49$ (common focus on cognitive capacities "reduce[s] the practical significance of [the] analyses by focusing on stress as an episodic, personal, or transient phenomenon, as opposed to the chronic, inescapable systemic horrors faced by the most deprived groups"; "[i]t may well be ... that most severely deprived criminal defendants are capable of practical reason, in the sense of being sane, or having any given level of measured intelligence, or possessing creative, resourceful, resilient or adaptive traits. . . . [This] should not detract from the various ways in which a person may be deprived of the capacity for responsibility.") 


\section{Why Compatibilism Marginalizes Hard Social Conditions}

Even though many compatibilists express the intuition that hard social conditions have some bearing on moral responsibility, then, contemporary compatibilism's responsibility inquiries do not make much room for consideration of the sorts of hard social conditions that are most common in modern Western society. In this Subpart, I suggest that contemporary compatibilism generally disregards hard social conditions because it cannot "see" the sort of process by which hard social conditions most commonly influence antisocial conduct. In the next Subpart, I contend that this blindness is likely to be a stubborn feature not only of contemporary compatibilism, but of compatibilism generally, for to "see" this kind of process would jeopardize one of compatibilism's core projects.

While there is notorious controversy about how hard social conditions influence human behavior, there is widespread agreement on some very basic points. For example, there is little dispute about the basic premise that hard social conditions like poverty, inequality, and discrimination are catalysts to antisocial conduct. ${ }^{128}$ There also appears to be agreement that hard social conditions can catalyze antisocial conduct even when they do not deprive actors of basic human capacities, ${ }^{129}$ foist anomalous attitudes on passive recipients, or truly

128. It is common to say that conditions like poverty and inequality are criminogenic. See, e.g., Delgado, supra note 11, at 23-37 (summarizing social scientific and medical literature on the contribution of environmental deprivation to criminal behavior); Patricia J. Falk, Novel Theories of Criminal Defense Based Upon the Toxicity of the Social Environment: Urban Psychosis, Television Intoxication, and Black Rage, 74 N.C. L. REV. 731, 758-83 (1982) (surveying the social science literature on the psychological effects of real-life violence, television violence, and racism); see also Deirdre Golash, The Case Against Punishment: Retribution, Crime Prevention, and the LAW 155 (2005) ("There is broad (though not universal) agreement among criminologists that social factors such as income inequality, poverty, unemployment, and local social disorganization contribute to crime."); id. at 155-72 (collecting and canvassing sources); NORVALL MORRIS, MADNESS AND THE CRIMINAL LAW 63 (1982) ("Social adversity is grossly more potent in its pressure toward criminality . . . toward all forms of violence and street crime . . than is any psychotic condition."). But see Morse, supra note 2, at 115 (poverty and deprivation are "strongly correlated with criminal behavior . . . but whether the correlation reflects a causal relation .... is [a] . . . controversial question").

129. See Arenella, supra note 58, at 82-83 (many actors develop basic capacities for instrumental reasoning, no matter what formative influences they encounter); Delgado, supra note 11, at 41 ("A defendant entering a ["rotten-social-background"] defense is asserting that adverse external forces have influenced behavior, not that he or she has a weak intellect."); Morse, supra note 2, at 144 ("[D]espite the undoubted stresses of their lives, few deprived people lack the general capacity to be guided by good reason."); Wright, supra note 71 , at 476 ("[I]t may well be . . . that most severely deprived criminal defendants are capable of practical reason, in the sense of being sane, or having any given level of measured intelligence, or possessing creative, resourceful, resilient or adaptive traits."). 
eliminate opportunities to act appropriately. ${ }^{130}$ Indeed, we generally recognize that hard social conditions seem to catalyze antisocial conduct among actors who are not fundamentally different from ourselvesactors who have the same basic capacities we have, the same ownershiprelation to their attitudes and desires that we have to ours, and who have genuine opportunities to act appropriately, just as we do. Most criminals are more or less complete, functional, and choosing persons, just like noncriminals.

If we think hard social conditions catalyze antisocial conduct, then, it is not (primarily) because we think such conditions deprive people of essential features and opportunities to act appropriately, but because we think these conditions influence how people use these features and opportunities. They do so by bringing to life antisocial desires, attitudes, and dispositions. Hard social conditions cause people to want things they are not supposed to want, and to want these prohibited things more badly than most people do. They cultivate antisocial feelings like anger, envy, anxiety, self-hatred, frustration, impotence, despair, and need. ${ }^{131}$ They foster antisocial attitudes like callousness, self-absorption, irritability, excitability, impulsiveness, disdain for social norms, disdain for authority, and insensitivity to violence or violence against particular targets. ${ }^{132}$ They nurture cognitive styles conducive to antisocial preferences, including socially unwelcome approaches to the weighing of risk and reward and the valuing of present and future gratification. ${ }^{133}$ In these ways, hard social conditions construct in actors the matrices of antisocial desires, attitudes, and cognitive styles that generate bad acts. In short, it is not that hard social conditions make people incomplete

130. Morse, supra note 86 , at 1653 (although hard social conditions can be criminogenic, social conditions that are genuinely coercive "rarely arise").

131. See Delgado, supra note 11, at 23-24 (hard social conditions instill frustration that leads to aggression); id. at 26-27 (unemployment and substandard living conditions produce envy and anxiety); id. at 64 (hard social conditions instill intense anger); id. at 81 (hard social conditions diminish "self-respect"); Falk, supra note 128, at 762 (violent environments lead to depression and anxiety); id. at 776-77 (racism leads to self-contempt, anger, frustration, and anxiety); Morse, supra note 2, at 142 (suggesting poverty entails "unsatisfied needs and desires" and "material want"); id. at 144 (connecting poverty to "rage" and "stress").

132. See Delgado, supra note 11, at 81 (citing theory that "vengeful, self-seeking behavior is a normal response to an oppressive social system," and that ["rotten social background"] may lead one to "[have] no attachment to the broader community, and [be] a constant source of misdirected rebellion").

133. See, e.g., id. at 46 (["rotten social background"] likely generates heightened sensitivity to potential danger); Falk, supra note 128, at 741 (citing Greg Seigle, Union Station Killer Gets 10Year Minimum, WASH. TIMES, June 10, 1994, at C10) (suggesting there may be a "defensive mindset prevalent in tough, inner-city neighborhoods"); Morse, supra note 86, at 1653 (suggesting that "deprivation" and "rotten social background" may "produce[] character flaws" and "antisocial predispositions"). 
persons or fragmented beings, nor that they deprive people of opportunities to act, nor that they inject into them alien desires and traits. Rather, we think that they work on people in gradual, incremental ways, making them complete, fully functional, coherent beings who want things they are not supposed to want, ${ }^{134}$ and giving them strong motives to act on those wants even when they have the capacity and opportunity not to.

If this is the way hard social conditions most commonly influence conduct, it is no wonder that contemporary compatibilism cannot "see" it. Contemporary compatibilism has a very particular taste when it comes to inquiry into desire and disposition formation. It is interested in circumstances and events that influence desires and dispositions in a distinctive and bizarre way-by sparking to life anomalous and transitory desires and dispositions, as guns-to-the-head and supernatural neurosurgeons do. But it has less interest in phenomena that shape desires and dispositions "normally," in a gradual, holistic way. Momentary invasions of the desire/disposition formation process matter, but otherwise, "the source . . . of the actor's goals, desires, and values that motivate his choice are [not] relevant . ..."135 "The sort of character a person has is relevant to assessing his moral responsibility for an action, but not how he came to have that character."136 In short, contemporary compatibilism's interest in desire/disposition formation extends only to a certain sort of abnormal and transitory desire/disposition acquisition. Because there is nothing abnormal or transitory about the way the sorts of hard social conditions found in modern Western society today shape desires and dispositions, contemporary compatibilism does not include most real-world hard social conditions in its responsibility determinations. It cannot see them.

\section{Resistance to Social Conditions as a Stubborn Feature of Compatibilism}

Contemporary compatibilism, then, cannot "see" the process by which common hard social conditions do their criminogenic work. But is this just a coincidence of current theory, or a more enduring feature of

134. See, e.g., Falk, supra note 128, at 763 (citing James Garbino et al., What Children Can Tell Us About Living in Danger, 46 AM. PSYCHOLOGIST 376, 377 (1991) (collecting literature showing that harsh social conditions can lead to "alterations of personality, and major changes in patterns of behavior or articulations of ideological interpretations of the world that provide a framework for making sense of ongoing danger").

135. Arenella, supra note 58, at 64

136. Vuoso, supra note 54, at 1681. 
compatibilism generally? In this Subpart, I argue that there is reason to think that lack of interest in such social conditions is at least a stubborn feature of compatibilism, if not an inevitable one. Making room for phenomena that influence conduct through this sort of gradual, holistic desire/disposition formation would jeopardize one of compatibilism's central projects.

The project I refer to is salvaging blame-by corralling excuse - in the era of causal explanation. ${ }^{137}$ Anxiety about the fate of blame in a causal world is a persistent feature of the compatibilist literature. When contemplating the possibility that we must excuse actors when their acts are caused by forces beyond their control, compatibilists ask "if we do that job right, will there be anyone left to blame?"138 The possibility that there will not is contemplated in terms redolent with danger and dismay. These are "drastic implications"139 and "highly undesirable." 140 They are "pernicious and debilitating," "di1 "disturbing,"142 "distressing,"143 "startling,"144 "troubling," "145 "perilous," "146 and even "tragic."147 When

137. I do not mean that the only aspect of compatibilism that is "satisfying" to compatibilists is its ability to salvage blame from causation. On the contrary, it appears that compatibilists have traditionally pursued several different sorts of projects at the same time. One is the project I focus on here. Another is the project of articulating an account of our blaming practices that is subtle enough to capture all their nuances. See, e.g., WALlACE, supra note 13, at 7 ("The possibility that determinism might be true gives an extra immediacy to the issue of whether it is compatible with moral responsibility, but the reason for considering this issue - my reason, at least-is to obtain an improved understanding of the conditions of responsibility ...."). Yet another is demonstrating that human life is valuable, satisfying, meaningful, and worth living even if determinism is true. All I suggest here is that one of the appealing features of compatibilism-for compatibilists - has been its ability to keep blame from being overwhelmed by causal explanation.

138. DENNETT, supra note 11, at 99; see also id. at 157 ("[S]ince we are all more or less imperfect, will there be anyone left to be responsible after we have excused all those with good excuses?"); FISCHER \& RAVIZZA, supra note 43, at 28 (stating that the possibility that originationism and determinism are both true leaves us "not clear that we can legitimately hold each other morally responsible for our behavior"); MOORE, supra note 1, at 504 (stating that if determinism and originationism are true, "it is hard to see why everyone is not excused for all actions"); Strawson, supra note 9, at 72 (Is it true "that if [determinism] is true, then the concepts of moral obligation and responsibility really have no application, and the practices of punishing and blaming, of expressing moral condemnation and approval, are really unjustified?"); $i d$. at 73 (some believe that "just punishment ... impl[ies] moral guilt and guilt implies moral responsibility and moral responsibility implies freedom and freedom implies the falsity of determinism" (emphasis omitted)).

139. WOLF, supra note 16, at 12.

140. Id. at 26 .

141. MOORE, supra note 1, at 490-91.

142. FISCHER \& RAVIZZA, supra note 43 , at 17.

143. Id. at 28 .

144. Id.

145. WALLACE, supra note 13 , at 3.

146. Meir Dan-Cohen, Responsibility and the Boundaries of the Self, 105 HARV. L. REv. 959, 960 (1992) ("Concessions to determinism are as inevitable as they are perilous ....").

147. MOORE, supra note 1, at 244. 
we think about them, we feel "fear," ${ }^{148}$ we talk "all in a rush"149 like a scared child, or we are made into "pessimists"150 and "cynic[s]."151 Blame is seen as "imperiled,"152 "engulf[ed]" by excuses. ${ }^{153}$ Responsibility is not merely called into question; it is "challenge[d]"154 and "threaten[ed]." 155 Sometimes it is suggested that there is something vulgar about the argument that actors should be excused for acts caused by forces beyond their control: it is "seductive," 156 exerting a "deep pull," $" 157$ with results "bordering on the indecent."158 And sometimes compatibilists in this vein seem to suggest that something more nefarious may be at work. Compatibilists portray originationists as cutting away responsibility slice by slice, making "lifelong effort[s] to expand the categories of those who should be excused," 159 scheming to "free the maximal number of defendants." 160 In the compatibilist literature, then, causal explanation is dangerous; if yoked to the wrong theory of responsibility, it "threatens" to do away with blame entirely.

One of compatibilism's projects is saving us from this fatesalvaging blame in a causal universe. ${ }^{161}$ "We are looking . . . for some elbow room for ... sinners in between the saints [who never do wrong]

148. See DENNETT, supra note 11, at 157 ("[O]ne thing we fear is that no one ever really deserves the punishment society metes out ....").

149. Strawson, supra note 9 , at 73 .

150. Id.

151. Michael S. Moore, The Determinist Theory of Excuses, 95 EтHICs 909, 916 (1985).

152. Strawson, supra note 9 , at 73 .

153. Moore, supra note 151, at 916.

154. FISCHER \& RAVIZZA, supra note 43, at 17.

155. Id.; WALLACE, supra note 13 , at 6,234 ; WOLF, supra note 16 , at 12.

156. WALLACE, supra note 13, at 58, 196; see also MOORE, supra note 1, at 491 (discussing the "seductive plausibility of the causal [originationist] theory of excuse").

157. WALLACE, supra note 13, at 196.

158. Id. at 234. In a related vein, he intones that we need "protection against the admittedly powerful lure of liberty," id. at 225 , and thinks of the desire for contra-causal freedom as "a kind of fetish." Id. at 3 .

159. Moore, supra note 151 , at 916.

160. Id. There are other passages in Moore that give the impression of responsibility being eaten away, too. See, e.g., MOORE, supra note 1, at 242-43 (moral luck thought experiments consume responsibility piece by piece)

161. Arenella and Corrado provide further discussion on this subject. See Arenella, supra note 54, at 1611-13 (discussing ways "the specter of determinism" has influenced moral and legal theory, noting "determinism's constant threat" and the "worry it causes," speculating that compatibilist criminal theorists have been attracted to choice theory because it appears to withstand "the onslaughts of determinism" better than some other compatibilist theories); Corrado, supra note 3, at 1206 ("[M]ost compatibilists believe that determinism is true but do not want to give up the right to hold people responsible"; compatibilism is "fuel[ed]" by "the attempt to avoid [the] conclusion" that "no one is responsible for anything."). 
and the monsters [whom we must excuse],"162 says Daniel Dennett. Strawson announces that his goal is to make the causation-preoccupied "pessimist" give up his worry that blame is unjustifiable. ${ }^{163}$ Compatibilism, say its proponents, gives us the elbow room we need; it helps the pessimist give up his pessimism about blame. Moore's compatibilism shows "there is ... no good reason to fear" that there is a "general moral excuse." the first step toward protecting our moral responsibility" from the "challenges" posed by determinism. ${ }^{165}$ They contend that "one of the great virtues of our approach to moral responsibility is that, on our account, it is highly plausible that moral responsibility is compatible with . . . determinism."166 Wallace "diagnoses" the problem like a disease, and provides "therapy" in order to cure it. ${ }^{167}$ His theory "deprives incompatibilism of its foothold in our understanding of the legitimate conditions of responsible moral agency."168 In short, compatibilist theories are not just good on their merits - not just good because they accurately capture or rationalize our blaming practices- they are good, too, because they protect blame from the rising tide of causal explanation.

One way to understand compatibilism, then, is to give it an instrumental account. Compatibilism is in part a reaction to powerful articulations of causal accounts of human acts. As explanations of events in terms of their causes have become more common, anxious questions have arisen. ${ }^{169}$ How can actors be morally responsible in a determined universe? How can we continue to blame and punish if determinism is true? How can we justify our retributive urges? ${ }^{170}$ Compatibilist philosophers have offered compatibilism as an answer to these questions, and a salve for the anxiety they entail. There is no need to give up blaming and punishing, they say, for blame and punishment are not moored in "metaphysical" freedom. In short, compatibilism has been

\footnotetext{
162. DENNETT, supra note 11 , at 157.

163. Strawson, supra note 9 , at 122.

164. MOORE, supra note 1, at 547.

165. FISCHER \& RAVIZZA, supra note 43 , at 54 (emphasis added).

166. Id. at 253 .

167. WALLACE, supra note 13 , at 225.

168. Id. at 224 .

169. Kane, supra note 11 , at 3.

170. "[O]ur understanding of the influence of genetic endowment and the environment on human conduct and character is constantly advancing, and this presses horizon issues [that is, issues about human responsibility,] on us with increasing force," such that "to refuse to consider them seems mere evasion." Russell, supra note 18, at 249-50.
} 
fashioned and marketed for its ability to salvage blame in a time of causal explanation. This is one of its central projects. ${ }^{171}$

If this is one of compatibilism's central projects, it is not hard to see why compatibilists are reluctant to attend to the sorts of hard social conditions endemic to modern Western society, for it is not clear that attending to hard social conditions is compatible with compatibilism's project. For one thing, hard social conditions are likely to be implicated in a very broad swatch of cases of antisocial conduct. If they have or can have excusing significance, the threat of overbroad excuse reappears. Moreover, hard social conditions affect conduct in a way that makes them similar to certain other phenomena, including genetic inheritance, formative family experience, and cultural conditioning, each of which also generates and sustains desires and dispositions in holistic, incremental ways, and each of which seems likely to be in play in many cases of antisocial conduct. ${ }^{172}$ If hard social conditions can have excusing significance, these sorts of phenomena may have it toomaking the threat of overbroad excuse even more pressing. Thus, where contemporary compatibilism's focus on cataclysmic incapacities and outlandish sources of desire/disposition formation assures that excuses will be available only in rare cases, attention to hard social conditionsand to other, similar phenomena - threatens to make excuses available in many or most cases of human conduct. At the very least, it generates a thorny problem of sorting holistic, desire/disposition-forming phenomena that excuse from those that do not - and doing so in a way that sustains blame in a significant portion of cases. If one of compatibilism's projects is to protect blame from being overrun, then, giving holistic desire/disposition-forming phenomena like hard social conditions excusing significance may seem dangerously like stepping out

171. This instrumental characterization of compatibilism raises the possibility that some of the energy in the free will debates arises from a sort of internecine struggle between old and new manifestations of individualist ideology. An outdated and increasingly ineffective individualist paradigm (free will) is being overtaken, torn down, and discarded by another "updated" individualist paradigm (compatibilism) that does a better job of advancing individualist ideology in contemporary society. The old one (free will) is outdated in that it cannot advance the individualist account very effectively in the face of the causal explanations that pervade modern popular political culture; the new one (compatibilism) is more effective precisely because it dispatches modern causal explanation so well — by declaring most such explanation irrelevant. The old paradigm — having fought off all challengers for several centuries, and having insinuated itself into popular philosophy in a hundred different ways - will not go easily into the night, and so the struggle between old and new individualist paradigms electrifies the free will debates.

172. See NORRIE, supra note 70 , at 169 ("There is no getting away from our existence in families, neighborhoods, environments, social classes and politics"; "[i]t is these contexts that deal us the card which we play ...."; and "individual actions are . . . mediated and conditioned" by "social context."). 
onto a steep and slippery slope, at the bottom of which is the very sort of overly broad excuse that compatibilism is constructed to avoid.

This is not to say that it would be impossible to conceive a version of compatibilism that drew the line differently, and made room for consideration of mundane, widespread social conditions like poverty and inequality, or for holistic, desire/disposition-shaping phenomena generally. Rather, the point is that it may be so dangerous to do so (from the compatibilist's point of view) that compatibilists will typically prefer other, less perilous routes, as they have so far, and that theorists who can tolerate the possibility of such broad excuse will also be dispositionally receptive to the intuitively appealing origination requirement as well. If so, resistance to social conditions is likely to be at least a stubborn feature of compatibilism.

\section{B. Originationism as More Attentive to Hard Social Conditions}

While compatibilism is structurally ill-equipped and dispositionally unlikely to attend to hard social conditions, originationism has features that make it well-suited to accommodate our intuitions about hard social conditions and responsibility. This is so because originationism can use a wider lens in its responsibility inquiry, and because the inquiry that originationism mandates - the causal inquiry - is more attuned to the way we think about the relationship between hard social conditions and antisocial conduct.

Recall that the originationist responsibility inquiry can be broader than the compatibilist inquiry. ${ }^{173}$ Originationism places limits on who can be blamed; it does not limit who can be excused. Thus, an originationist can accept any of the compatibilist excusing conditions, and engage in any of the responsibility inquiries that the compatibilist might engage in. But the originationist must also go further. Unlike the compatibilist, the originationist must excuse actors whose acts are caused by forces beyond their control. Thus, the originationist may engage in the same sorts of feature/opportunity, ownership, and evidentiary inquires that the compatibilist engages in, but he must also make the further inquiry into whether the actor's acts were caused by forces beyond his control-entirely apart from whether such forces deprived him of particular features, instilled in him alien attitudes, or foreclosed a

173. See Delgado, supra note 11, at 22 (characterizing Bazelon's originationist rotten-socialbackground defense as entailing a "broadened inquiry into culpability"); Wright, supra note 71, at 463 (characterizing responsibility inquiries that exclude social conditions as "truncated" inquiries). 
fair opportunity to act. In this sense, the originationist inquiry can be broader than compatibilism's. ${ }^{174}$

Moreover, originationism's attention to causation makes it more likely to make hard social conditions a part of this broad inquiry. This is so because originationism is attuned to causation, and most of us are susceptible to the idea that common hard social conditions play a causal role in human acts. ${ }^{175}$ This is not to say that we are convinced that all bad acts are the product of hard social conditions; most people probably do not believe that. Nor is it to say that we are confident in our ability to map out the causal relationships between particular hard social conditions and specific bad acts. On the contrary, we often have deep misgivings about efforts to explain specific acts by reference to particular causes, social or otherwise. Nor is it to suggest that we are likely to spontaneously imagine such explanations. As Part IV will suggest, our sensitivity to such causal explanations is probably susceptible to manipulation. Nevertheless, most of us are open to the possibility that there are causal explanations for at least some human acts, and that common hard social conditions like poverty, inequality, and discrimination have a place in some of these explanations. As a result, when an actor claims that hard social conditions played a causal role in her act, the originationist is likely to listen. The originationist considers such claims empirically plausible (as most of us do) and morally relevant (as originationists, but not compatibilists, do). ${ }^{176}$

In short, the originationist is more likely to inquire into hard social conditions than the compatibilist. Originationism is amenable to any responsibility inquiry the compatibilist might make, but it also mandates further inquiry. Moreover, originationism's attention to causation makes it naturally interested in the relationship between hard social conditions and crime. Thus, where compatibilism tends to marginalize or make

174. See Corrado, supra note 3, at 1192 (noting that originationism is more likely than compatibilism to accommodate "abusive background" defenses and "genetic constitution" defenses).

175. See Delgado, supra note 11, at 66 n.370 (noting that while we generally cannot be absolutely certain of the way social conditions cause acts, science, "intuitive wisdom," and "common sense" can flesh out causal accounts sufficiently for us to rely upon them); id. at 20 ("[E]nvironment must be accounted for in assessing criminal responsibility . . . ."); id. at 23-34 (providing thorough (though perhaps outdated) catalog of conventional theories about the ways in which hard social conditions cause criminal conduct); John L. Hill, Freedom, Determinism, and the Externalization of Responsibility in Law: A Philosophical Analysis, 76 GEO. L.J. 2045, 2048 (1988) (surveying various causal accounts of human conduct, acknowledging present uncertainty about precise details of such accounts, but confident that such accounts exist).

176. See Vuoso, supra note 54, at 1661 (noting that "[i]t is a widely held belief that a disadvantaged socio-economic background can mitigate or eliminate responsibility" and associating this view with orignationism). 
invisible the connections between hard social conditions and antisocial conduct, such connections are solidly in originationism's sight lines.

\section{Summary}

Compatibilism and originationism, then, treat social conditions differently. Contemporary compatibilism's responsibility inquiries are unlikely to attend to hard social conditions in a meaningful way, and there is reason to believe that this is at least a stubborn feature of compatibilism. Originationism, in contrast, is more likely to consider the role that hard social conditions play in a human act, and thus to attend to social conditions while evaluating an actor's responsibility. The next Part shows that this difference has political ramifications in the context of the criminal law.

\section{THE POLITICAL CONSEQUENCES OF THE COMPATIBILIST CRIMINAL LAW}

Because compatibilism and originationism take such different approaches to hard social conditions, compatibilist and originationist criminal justice systems influence the allocation of power and resources in society in different ways. Thus, cultivating a compatibilist criminal law can have political consequences. This Part describes two such consequences. Part IV.A argues that a compatibilist criminal law is more likely to disrupt criticism of and challenges to the social status quo. This is because the compatibilist criminal law's unwillingness to consider social conditions in the responsibility inquiry can impair popular recognition of the links between social conditions and crime. Part IV.B contends that a compatibilist criminal law is more likely to facilitate the state's use of violence to reinforce the status quo. This is because its resistance to social condition excuses makes it more likely to authorize the state to act violently against the disadvantaged, perpetuating their disadvantage and deterring them from engaging in social criticism and resistance. ${ }^{177}$ Thus, the more the state commits to the compatibilist approach to criminal law, the more powerful the ideological and coercive weapons it can use to defend the social order.

177. Part IV.A, it might be said, is about the compatibilist criminal law as political persuasion. Part IV.B is about the compatibilist criminal law as political violence. 


\section{A. Compatibilism and Ideology: How the Compatibilist Criminal Law Disrupts Criticism of the Status Quo}

Modern Western states like the United States have significant crime problems, and such crime problems have the potential to catalyze criticism of and challenges to the existing social order. The intensity of this threat, however, can be influenced by the state's approach to criminal responsibility. Here, I argue that the more the state takes the compatibilist approach to criminal responsibility, the less likely it is that the crime problem will catalyze such challenges, for a compatibilist criminal law disrupts popular sensitivity to the part social conditions play in the crime problem.

1. The Crime Problem as a Potential Catalyst for Challenges to the Social Order

The United States (like many modern Western states) has an enormous crime problem. In a typical year, there are more than five million violent crimes in the United States, ${ }^{178}$ including between fifteen and twenty-five thousand criminal homicides, ${ }^{179}$ two-hundred thousand reported sexual assaults, ${ }^{180}$ and one million aggravated assaults. ${ }^{181}$ There are also more than eighteen million property crimes each year, including more than three million burglaries. ${ }^{182}$

Needless to say, crime on this scale entails significant physical and psychological suffering for an enormous number of crime victims, as well as their families and friends. It also exacts an extraordinary

178. Shannan N. Catalano, U.S. Dep'T of Justice, Criminal Victimization, 2004, at 2 tbl.1 (2005), available at http://www.ojp.usdoj.gov/bjs/pub/pdf/cv04.pdf.

179. See id. (16,500 in $2004 ; 15,900$ in 2003). Since 1990 , the number has ranged between approximately 15,000 and approximately 25,000. BUREAU OF JUSTICE STATISTCIS, U.S. DeP'T OF Justice, Homicide TRENDS IN THE U.S.: Homicide VictimizATION, 1950-2004 (2006), http://www.ojp.usdoj.gov/bjs/homicide/tables/totalstab.htm.

180. According to the Bureau of Justice National Crime Victimization Survey, there were 198,850 rapes and sexual assaults reported in 2003, and 209,880 in 2004. CATALANO, supra note 178 , at 2 tbl.1. The actual number of rapes and sexual assaults is likely much higher, as these crimes are notoriously underreported.

181. Id. There are typically more than four million simple and aggravated assaults combined. See Bureau of Justice Statistics, U.S. Dep'T of Justice, Criminal Victimization in the United STATES, 2003 StATISTICAL TABLES (2005), available at http://www.ojp.usdoj.gov/bjs/pub/ pdf/cvus03.pdf (4,606,740 in 2003).

182. See Catalano, supra note 178, at 2 tbl.1 (18,626,000 in 2003; 18,654,000 in 2004). The figures include more than three million household burglaries and more than one million auto thefts each year. Id. 
economic cost. In the United States, the medical expenses, lost wages, and other tangible costs associated with crime can exceed one hundred billion dollars in one year. ${ }^{183}$ Federal, state, and municipal governments spend well over one hundred billion dollars a year on the law enforcement, investigation, judicial proceedings, and correctional facilities dedicated to prosecuting and punishing crime. ${ }^{184}$ Adding the cost of private security measures and other costs of crime, "[t]he net annual burden of crime [may] . . exceed \$1 trillion." "185 And none of this takes account of the other ways the crime problem impoverishes us - by causing us to worry about crime even when we ourselves are not victims, making us reluctant to travel to certain places or at certain times, or inducing us to tolerate a regime of uncomfortably intrusive police practices.

The natural responses to a social phenomenon responsible for so much suffering and such extraordinary costs include fear, frustration, resentment, and anger. The natural sequel to such dissonant feelings is a demand for change. But just what should be changed? The answer to that question has political significance. Should citizens come to see existing social conditions as significantly implicated in the crime problem, the desire for change may become a desire for social transformation, and this desire may catalyze challenges to the existing social order.

\section{How Compatibilism Disrupts Challenges to the Social Order}

The crime problem will only catalyze challenges to the social order if the populace sees the social order as implicated in the crime problem. The state can influence the extent to which the populace makes this connection by its approach to criminal responsibility: the more the state

183. See Ted R. Miller et Al., NAtional Institute of Justice Research Report: Victim COSTS AND CONSEQUENCES: A NEW LOOK 6 (1996), available at http://www.ncjrs.gov/pdffiles/ victcost.pdf (summing cost of crime victim medical expenses, lost earnings, and "public program" costs to $\$ 105$ billion and speculating that "pain, suffering, and the reduced quality of life increases the cost of crimes of victims to an estimated $\$ 450$ billion annually," with $\$ 426$ billion attributable to violent crime and $\$ 24$ billion to property crime).

184. "Direct expenditure for police protection, judicial and legal services, and correctional activities in 2001 in the United States was a record \$167 billion for local, state and federal government." Bureau of Justice Statistics, U.S. DeP'T OF JUSTICE, Justice EXPENDitures AND EMPLOYMENT IN THE UNITED STATES, 2001 (2004), http:/www.ojp.usdoj.gov/bjs/pub/pdf/ jeeus01.pdf. This included $\$ 72,406,000,000$ on law enforcement, $\$ 37,571,000,000$ for judicial expenditures, and \$56,956,871,000 for corrections. BUREAU OF JUSTICE STATISTICS, U.S. DEP'T OF Justice, DiRECT EXPENDITURES BY CRIMINAL JustiCE FunCTION, 1982-2003 (2006), http://www.ojp.usdoj.gov/bjs/glance/tables/exptyptab.htm.

185. David A. Anderson, The Aggregate Burden of Crime, 42 J.L. \& ECON. 611, 611 (1999). 
adheres to a compatibilist approach to criminal responsibility, the less sensitive the populace will be to the relationship between social conditions and crime, and the less likely it will be that the crime problem will issue in challenges to the social order.

The argument here assumes that the state's approach to criminal responsibility influences the way citizens in general think about criminal responsibility. The common view that the criminal law serves an educative function supports this assumption: if prohibitory norms are disseminated and inculcated through the criminal law, ${ }^{186}$ it is likely that the theory of responsibility is also bound up with these norms. More concretely, when the state adopts a theory of criminal responsibility, state actors become public advocates for that theory. Legislators, judges, and executive actors articulate it in explicit and implicit, complete and incomplete ways. As they do so, they make the theory intellectually accessible and give it the seal of authoritative approval. At the same time, state institutions model the application of the theory. In particular, the state's criminal courts apply the theory to tangible cases in a vivid, endlessly repetitive way, demonstrating it not only for all those who participate in the trial, but also for all those otherwise interested in the outcome and for the community as a whole. ${ }^{187}$ Such modeling makes the state's approach to criminal responsibility seem not just comprehensible and appealing, but normal and inevitable. Thus, the state's approach to criminal responsibility is likely to influence the way the populace thinks about criminal responsibility. ${ }^{188}$

By influencing the way the populace thinks about criminal responsibility, the state influences the populace's sensitivity to the connections between social conditions and the crime problem. ${ }^{189}$ As we have seen, some ways of thinking about criminal responsibility are more likely to identify connections between social conditions and crime than others are, for the different approaches to responsibility show different

186. See Paul H. Robinson \& John M. Darley, The Utility of Desert, 91 Nw. U. L. REV. 453, 471 (1997) (criminal law plays a "central role in the creation of shared norms").

187. See David L. Bazelon, The Morality of the Criminal Law, 49 S. CAL. L. REV. 385, 391 (1976) (criminal trials are an opportunity for the "community . . . to learn . . . and . . . understand . . . the criminal responsibility issue"); see also Delgado, supra note 11, at $21 \mathrm{n} .82$ (noting that while there are a variety of ways to educate the public about crime, "the lesson society learns [from criminal trials] . . . [is] uniquely and conspicuously urgent"); Robinson \& Darley, supra note 186, at 472 (noting the educative impact of "law enforcement and adjudication activities").

188. This point is implicit in Boldt's contention that the criminal law "is a vital societal mechanism by which [the individualist] perspective [regarding responsibility] is created and maintained, and the causal . . . perspective obscured." Richard Boldt, The Construction of Responsibility in the Criminal Law, 140 U. PA. L. REV. 2245, 2247 (1992).

189. Delgado, supra note 11 , at 21. 
levels of interest in social conditions. Where the state models and recommends the originationist approach, citizens will learn to evaluate individual responsibility by inquiring into (among other things) the causes of antisocial conduct. ${ }^{190}$ Given the plausibility of the view that hard social conditions can cause antisocial conduct, such citizens will naturally consider whether hard social conditions are involved in individual cases. As a result, the more closely the state hones to the originationist approach, the more the state encourages the populace to contemplate and debate the connections between individual antisocial acts and the broader social context. In such a state, we should expect to see claims and theories about the role of social conditions in crime playing a significant role in judgments about individual criminal responsibility and in discussion of the crime problem generally. ${ }^{191}$

The more the state pursues the compatibilist approach, on the other hand, the more it discourages contemplation and discussion of the connection between social conditions and crime. Where the state models and recommends the compatibilist approach, citizens will learn to evaluate individual responsibility by making feature/opportunity inquiries, ownership inquiries, and related evidentiary inquiries, and they will be sensitized to bizarre and transitory desire and disposition-shaping phenomena (nefarious hypnotists and their ilk); but they will not so readily recognize phenomena that shape actors' desires and dispositions in gradual and holistic ways, as common social conditions do. In such a state, we should not expect claims and theories about the role of social conditions in crime to play a significant part in judgments about

190. In fact, it appears that citizens in our society do think this way, at least some of the time. See supra Part III.A. This is at least indirect evidence against the descriptive claim that there is no originationism in our criminal law, and it is consistent with the more realistic claim that our criminal law contains both originationist and compatibilist strands. I say more about this in Part V.

191. See United States v. Alexander, 471 F.2d 923, 965 (1973) (per curiam) (reasoning that adopting the rotten-social-background defense will lead us to see the role of socioeconomic inequality in the crime problem); Bazelon, supra note 187, at 391 (suggesting that originationist criminal law catalyzes inquiry into "community's responsibility" for "the criminal act"); Delgado, supra note 11, at $21 \& \mathrm{n} .82$ (highlighting the way an originationist rotten-social background defense would inspire inquiry into the relationship between social conditions and crime while nonoriginationist approach "conceals" such connections); id. at 54 (stating that if the rotten-socialbackground defense were adopted, "the societal deprivation which results in crime among the poor would be exposed"); $i d$. at 67 ("His or her trial will expose the public to the RSB conditions that predisposed the defendant to crime . ..."); $i d$. at 87 (concluding that having a rotten-socialbackground defense "can enable society to recognize . . . the causes of environmentally induced alienation and anger"); Falk, supra note 128, at 811 (noting that recognition of social conditions defenses correlates with the recognition of society's "sometimes deleterious effects on the human psyche"); Hill, supra note 175, at 2071 (stating that if we use an originationist approach that properly accounts for "genetic, socioeconomic, and environmental factors," then "society itself becomes responsible" and "society's collective attention may be directed to those larger conditions which cause, and become manifest in, individual deviant acts"). 
individual responsibility, nor in discussion of the crime problem generally. On the contrary, such claims and theories will be hard to conceive and articulate, and even when offered they will seem controversial, ${ }^{192}$ unreliable, ${ }^{193}$ pathological, ${ }^{194}$ and corrupt. ${ }^{195}$ In short, the more the state takes the compatibilist approach to criminal responsibility, the more unlikely it is the populace will see social conditions as implicated in crime in a significant way. ${ }^{196}$

It follows that the state's approach to criminal responsibility can significantly influence whether the crime problem generates popular challenges to the social order. The more the state takes the originationist approach, the more readily the populace will associate social conditions with the crime problem; and the more the populace associates social conditions with the crime problem, the more likely it is that the populace will seek to alleviate the enormous suffering and costs associated with the crime problem through criticism of and challenges to the existing social order. ${ }^{197}$ If citizens perceive that social conditions are bound up

192. Compatibilist theorists commonly warn that originationist claims are "controversial," WOLF, supra note 16, at 39, or "complex and contentious," FISCHER \& RAVIZZA, supra note 43, at 187.

193. Originationist intuitions will be treated as optical illusions - enticing, but fundamentally misleading. See MOORE, supra note 1, at 544 (comparing our originationist intuitions about social conditions to our perceptions of sticks half-submerged in water, which appear bent even though they are not). It will be said that they cannot bear "too much weight," WOLF, supra note 16, at 39, and should be put aside in favor of "clear[er] cases," FISCHER \& RAVIZZA, supra note 43, at 187.

194. Originationist ideas will be seen as a kind of obsessive idealism, a "misplaced reverence for an absolutist ideal." DENNETT, supra note 11, at 165. "St. Peter may wish to do greater 'fine tuning,' but the law should not." Stephen J. Morse, Justice, Mercy, and Craziness, 36 STAN. L. REV. 1485,1499 (1984).

195. Originationist claims will be said to harbor secret "elitism and condescension," and to deny "the equal moral dignity of others." MooRe, supra note 1, at 545-46; see also id. at 148-49 ("Such discrimination is a temptation to be restricted, because it is no virtue. It is élitist and condescending toward others not to grant them the same responsibility and desert you grant to yourself."). For another account suggesting that there is something corrupt about these sympathetic attitudes, see DENNETT, supra note 11, at 167.

196. See Delgado, supra note 11 , at $21 \& \mathrm{n} .82$ (suggesting that adoption of an originationist rotten-social-background defense would have this effect).

197. See GolASH, supra note 128, at 120,149, 153 (recognizing role of social circumstances in crime leads us to see that "it is inappropriate for the state to seek to improve [wrongdoers] characters rather than change their circumstances," and provides "incentive for more aggressive attempts to address the broad social causes of crime" and for "address[ing] the structural, cultural, and psychological causes of crime"); Arenella, supra note 58, at 83 (seeing how hard social conditions undermine moral development "might motivate us to do something about those conditions"); Delgado, supra note 11, at $21 \& \mathrm{n} .82$ (suggesting that if populace sees social conditions like poverty and inequality as implicated in crime, populace "would presumably decide to do something about" this, people would develop an "urgent" "determination to alter the social conditions which breed crime," they would seek "income redistribution coupled with other social reform measures," and "the lesson society learns [from presentation of an rotten-social-background defense in a criminal trial] and its determination to alter the social conditions which breed crime are uniquely and conspicuously urgent"); Hill, supra note 175, at 2045, 2071-72 (suggesting that the originationist 
with crime, they "may . . . take measures to avoid creating additional [rotten-social-background] individuals"; 198 they may seek "income redistribution,"199 "egalitarian redistribution of opportunities,",200 "social reconstruction," steps toward solving the problem of violent crime." 203 They may choose to "underwrite a legal and political process of egalitarian redistribution of freedom, control, and knowledge in favor of the most deprived." 204

On the other hand, the more the state takes the compatibilist approach, the more unlikely it is that the populace will make such challenges to the social order. ${ }^{205}$ In the compatibilist state, citizens are unlikely to see connections between social conditions and the crime problem, and if citizens do not see such connections, the crime problem will not inspire criticism of or challenges to the social order. Instead, the anguish and frustration generated by the crime problem will be directed at other, more "visible" 206 sources of crime. "Common sense" will declare that because "crimes and moral wrongs are ultimately committed by individual agents," solutions to the crime problem must focus on reforming, rewiring, constraining, or eliminating the individuals who engage in antisocial conduct. ${ }^{207}$ Alternatively, citizens will focus their

approach motivates "action against larger institutions" and attending to "the causes of negative behavior" leads to "reorganizing social institutions and addressing environmental concerns").

198. Delgado, supra note 11 , at 67.

199. See id. at 21 (referencing United States v. Alexander, 471 F.2d 923, 965 (D.C. Cir. 1973) (per curiam) (Bazelon, J., dissenting)); see also GOLASH, supra note 128, at 155-56 (discussing the relationship between crime and income inequality).

200. See Wright, supra note 71, at 500 (suggesting that this might be necessary to enable deprived actors to become responsible actors).

201. This is Judge Bazelon's phrase. Alexander, 471 F.2d at 965.

202. Delgado, supra note 11 , at 21 .

203. Alexander, 471 F.2d at 965.

204. Wright, supra note 71 , at 502; see also GoLASH, supra note 128, at 155-72 (discussing alternative ways of preventing and responding to crimes).

205. See Bazelon, supra note 187, at 401-02 (noting how different approaches to punishment link up with "alternative responses to the crime problem," including different attitudes toward addressing the "social and economic causes of crime"); Delgado, supra note 11, at 21 (referencing Alexander, 471 F.2d at 965, and noting Judge Bazelon's view that the insanity defense, which fails to account for impact of social conditions on mental functioning, "conceals the need for . . . reform"); $c f$. Wright, supra note 71, at 486 (making the distinct but related point that "to refuse to recognize the possibility of nonresponsibility due to severe deprivation is to fail to recognize the profound moral importance of reforming the conditions of social life").

206. See Hanson \& Yosifon, supra note 70, at 135 ("Because of our biases, individuals most likely to be held personally responsible are the salient individuals closest to the injury ....").

207. See Stephen J. Morse, Hooked on Hype: Addiction and Responsibility, 19 LAW \& PHIL. 3, 44-45 (2000) (explaining that social explanations for crime should not "undermine our view that most wrongdoers are responsible agents"). "Consideration of remote causes is of no help . . . . Rather, we must find the person in who the decisive junction of causes lies." Schlick, supra note 47, at 54, 61. Thus, if we have a crime problem, it is because individual actors fail to "buck up." 
ire on the law enforcement machinery that "fails to prevent" that conduct, or the educational institutions that fail to instill proper values. In oceanic moments, they will rail against - or resign themselves to"evil" itself. $^{208}$ Insensitive to the criminogenic effects of social conditions, the populace will naturally turn its frustration and anguish about the crime problem on other targets, leaving the social order undisturbed. In short, the more the state takes the compatibilist approach, the more unlikely it is that the crime problem will catalyze challenges to the social order.

This is not, of course, an air-tight dynamic. For example, it is likely that some people will be stubborn originationists, no matter what the state does. Even if the state takes and aggressively promotes a compatibilist approach to criminal responsibility, stubborn originationists will continue to think about the role of social conditions in antisocial conduct, and, as a result, to generate social criticism. But we should not expect such holdouts to be very common. The state is an influential opinion leader, and the state can articulate and model its preferred approach over and over again through the tens of thousands of criminal trials that take place every year. It is fair to expect that the state's approach will have a significant influence on how many-even if not all — citizens think about criminal responsibility.

Morse, supra note 86, at 1617-18. After all, "[h]ow hard is it not to offend the law? The criminal law sets very low standards; it asks very little of us . . . . [I]t is simply not that hard to obey." Morse, supra note 194, at 1498-99; see also Arenella, supra note 54, at 1614 (recognizing that "some moral agents will have a far easier time than others in exercising their moral capacities," but emphasizing that "the moral norms implicated by crimes barring physical and sexual violence against other human beings place minimal restraints on the agent's ability to pursue his own interests"). Thus, as one theorist observes, the "concept of responsibility" is used to "delineate the boundaries between those consequences for which the individual will be held accountable and those for which society will be so held." Hill, supra note 175, at 2046; see also Arenella, supra note 54, at 1533 (affixing moral blame to harm-causers "soothe[s] our collective social conscience"); J.M. Balkin, The Rhetoric of Responsibility, 76 VA. L. REV. 197, 262 (1990) ("To the extent that we believe that the cause of poverty is individual sloth, we divert blame from social practices and institutions.").

Deirdre Golash observes that "retributivists tend to assume that the rate of crime at any given moment is a result of the choices of individuals who choose to commit crimes." GolasH, supra note 128, at 90. I agree with Golash, but add the observation that among retributivists, compatibilists are more likely to focus on the responsibility of the individual than originationists, especially as causal accounts of human acts gain currency.

208. Moore, for example, invites us to vent our frustration about the crime problem against "evil" itself. "[T]here is such a thing as evil . . . it is . . a part of creatures not so different from ourselves." MOORE, supra note 1, at 142. One might say that what Moore has done is hone in on the space usually occupied by social conditions in our explanations of human acts, and replaced those social conditions with the phenomenon he calls "evil." Curiously, Moore at one point makes what seems almost a Freudian slip: urging us to see actors as bad in themselves, he declares that "we live in a society in which there really are fearful and awful people." Id. at 143 (emphasis added). Though he means to emphasize the "evil" in individuals, he seems at the same time to inadvertently indict the society (it is the sort of society in which bad people appear). 
It is also true that even if citizens take the compatibilist approach, and therefore decline to inquire into social conditions when trying to determine criminal responsibility, they might still look into the relationship between social conditions and antisocial conduct for other reasons - such as figuring out how to solve the crime problem. After all, it is perfectly possible to separate these two questions: (1) Does this actor deserve punishment? (2) Why did this actor commit this act? A person might block out social conditions while answering the "desert" question, yet be receptive to causal claims about social conditions while answering the "why" question. There is certainly nothing logically inconsistent about doing so. But, again, we should not overestimate the likelihood that citizens will separate the "desert" question from the "why" question. For one thing, the "desert" question generally seems more vivid and pressing than the question of why a person did what he did. ${ }^{209}$ The "desert" question, after all, is bound up with urgent and visceral feelings in a way the "why" question generally is not-it helps us figure out where to direct our angry, vengeful, resentful reactive attitudes. For another thing, while the "desert" question and the "why" question are logically separate questions, it is easy to conflate them. If the "desert" question yields the answer that the actor is "responsible" for his crime, it is easy (and psychologically economical) to slip into thinking that this means that the significant causes of his crime are in him, not his circumstances. ${ }^{210}$ As a result, we are more likely to try to answer the "desert" question than the "why" question, and answering the "desert" question will often exhaust our interest and/or draw our attention to powerful and distracting reactive emotions. ${ }^{211}$ Thus, if our analysis of the "desert" question does not attend to social conditions, we will often overlook inquiry into social conditions entirely.

The claim here is not that the state can turn on and off our sensitivity to the connections between social conditions and crime, like a light bulb. Obviously, we are not such puppets to the state, nor such single-minded thinkers. But there are good reasons to expect that the state's approach

209. See Delgado, supra note 11, at $21 \mathrm{n} .82$ (stating that while there are in theory a number of ways to lead people to think about social conditions and crime, criminal trials are "uniquely and conspicuously urgent").

210. See Hill, supra note 175, at 2067 ("When an unfortunate or harmful event occurs there is a natural human tendency to discover its cause. The notion of responsibility meets this need: by making one or more persons 'responsible' for an act, we pick them out as the 'cause' of the act." (citation omitted)).

211. See id. (noting that attributing responsibility to individuals can serve a "scapegoat function . .. placing the blame on an individual or group who is not a significant contributor to the harm at issue"). 
to criminal responsibility is likely to influence the way most of us think about criminal responsibility most of the time, and good reasons to think that our approach to criminal responsibility will influence whether and how much we look into the role of social conditions in crime. If this is true, the state's adoption of the compatibilist approach to criminal responsibility can go some distance toward impairing or blunting our sensitivity to the contribution of social conditions to crime, and thereby diminish the likelihood that we will vent our frustration about the crime problem against the existing social order.

In this sense, the choice between originationism and compatibilism involves a secret politics. The originationist approach to criminal responsibility can catalyze potentially transformative scrutiny of the social order; the compatibilist approach is more likely to defuse social criticism by keeping the undesirable criminogenic features of hard social conditions hidden from critical view. To choose compatibilism over originationism is, then, to choose an approach that favors maintenance of the existing social order, and to reject an approach more conducive to social change. ${ }^{212}$

\section{B. Compatibilism and Coercion: How the Compatibilist Criminal Law Facilitates State Violence in Defense of the Social Order}

There is another politically significant difference between the compatibilist criminal law and the originationist criminal law: the compatibilist criminal law is more conducive to state violence in defense of the social order.

The argument in this Subpart starts with the straightforward observations that criminal punishment is a significant form of state violence, that the state can at least partially "legitimate" this sort of violence by making criminal responsibility a prerequisite for punishment, and that this legitimating strategy can have the effect of constraining the state's use of the punishment power. Building on these premises, this Subpart shows that originationist and compatibilist approaches to

212. While this feature of the compatibilist criminal law usually remains beneath the surface, it does occasionally erupt into view. Thus, one compatibilist theorist, critiquing an apparently originationist rotten-social-background defense proposal, warns us that the proposal really aims at or suggests "massive redistribution of wealth," Stephen J. Morse, The Twilight of Welfare Criminology: A Final Word, 49 S. CAL. L. REV. 1275, 1276 (1976), "social engineering . . incompatible with a libertarian and capitalist society," id., "social reforms [that] would leave little private wealth for individual citizens," Stephen J. Morse, The Twilight of Welfare Criminology: A Reply to Judge Bazelon, 49 S. CAL. L. REV. 1247, 1261 (1976) [hereinafter Morse, Reply], and, ultimately, the overthrow of our "political and economic system." Id. 
responsibility constrain this sort of state violence in different ways, and that, under certain conditions, the compatibilist criminal law is more conducive to the use of state violence against the disadvantaged. This, in turn, has political consequences. It means that the compatibilist criminal law better enables the state to use the punishment power to disempower those at the bottom of the social order, and to suppress their criticism of the status quo.

\section{Punishment as State Violence}

The modern state typically claims the authority to treat men brutally in at least two sorts of situations: ${ }^{213}$ it claims the authority to engage in war and the authority to punish its criminals. ${ }^{214}$ The authority to inflict violence in the course of war is said to be a narrow one: it exists in certain sorts of emergencies, and it does not entail any sort of general authority to inflict violence directly upon the state's own citizens. The authority to punish criminals is not subject to such limitations; it authorizes the state to inflict violence on its own citizens, and to do so on a massive scale.

And, indeed, that is what the typical modern state does. In the name of criminal punishment, citizens are executed; they are forcibly removed from family, home, and community, and placed in physically and psychologically torturous conditions for years, decades, and lifetimes; their reputations are devastated and their prospects for fruitful lives destroyed. ${ }^{215}$ This year, for example, the United States will hold more than two million citizens ${ }^{216}$-including nearly one out of every one hundred men $^{217}$ - in prison. Many will be assaulted, raped, ${ }^{218}$ or killed

213. Various accounts break out the state's coercive powers in different ways. For an alternative view, see Corrado, supra note 1, at 259, distinguishing retributive punishment from utilitarian coercion.

214. See PETTIT, supra note 43, at 125-26 (the state "is a collective subject to which we give a special status .... [W]e take it to have a uniquely legitimate claim on the use of force . . . even when that force is deployed against individual members"); id. at 155 (state has a "monopoly of legitimate force . . . [including] a coercive power . . . of punishing those who offend against that code, say by imposing fines, imprisonment, or even execution").

215. "These devices are what I call the coercive machinery of the criminal justice system." Corrado, supra note 1, at 262.

216. One source puts the total number of prisoners incarcerated in the United States in 2003 at 2,212,475. Paige M. Harrison \& Allen J. BeCK, U.S. DeP'T OF Justice, Prisoners in 2003, at 1 (2004), available at http://www.ojp.usdoj.gov/bjs/pub/pdf/p03.pdf. State and federal authorities held 1,470,045 prisoners at the end of 2003. Id.

217. See id. (indicating that about one in 109 men were sentenced prisoners under the jurisdiction of state or federal authorities).

218. Given victim reluctance to report sexual assault and the potential for institutional 
by fellow prisoners or by guards. ${ }^{219}$ Some will be executed. This is state violence on a massive scale.

\section{How Making Criminal Responsibility a Prerequisite of Punishment Legitimates and Constrains the State's Violence}

The state's infliction of such violence can be threatening and alienating to the populace, and may trigger popular resentment and resistance. To preserve its punishment power, the state may take steps to legitimate its use of that power. One especially effective legitimating strategy is making criminal responsibility a prerequisite for the infliction of criminal punishment. But while this legitimating strategy can shore up the state's power to punish, it can also limit when and against whom the punishment power is used.

When the state inflicts violence on its citizens in a public and pervasive way, citizens may wonder what is to stop the state from bringing its extraordinary destructive power to bear on them, or on those they love, value, or identify with. They may also find it difficult to identify with the state should it inflict suffering arbitrarily or according to criteria that do not seem "just," "moral," or familiar. ${ }^{220}$ Because such fear and alienation can breed resentment and resistance, states sometimes seek to reassure their citizens about their exercise of the punishment power by mooring it to politically and morally "legitimate" procedures and principles. ${ }^{221}$ For example, the state may publicly commit to the rule of law, due process, and robust adjudicatory institutions, thereby reassuring its citizens that the punishment power will not be exercised in

embarrassment, there is tremendous uncertainty about the number of sexual assaults that are committed in U.S. prisons each year. Publicized guesses range from 200,000, Charles M. Sennott, Prison's Hidden Horror, Boston GloBe, May 1, 1994, available at 1994 WLNR 2057263, to one million, Michael Murphy, Prison Culture Twists Spirits of Jailer, Inmates, THE PATRIOT LeDGER (Quincy, Mass.), May 26, 2004, available at 2004 WLNR 17145715. "In 1974 it was estimated that of the forty-six million Americans who will be arrested at some time in their lives, ten million will be raped while in prison. . . R Rape is 'rampant' in our country's prison system." David M. Siegal, Rape in Prison and AIDS: A Challenge for the Eighth Amendment Framework of Wilson v. Seiter, 44 STAN. L. REV. 1541, 1547 (1992).

219. Inmate violations in confinement facilities under federal or state authority between July 1 , 1999, and June 30, 2000: 34,355 assaults on inmates, 51 resulting inmate deaths. JAMES J. STEPHAN \& JeNNIFER C. KarberG, U.S. DeP’T OF Justice, Census of State AND Federal Correctional FACILITIES (2000), available at http://www.ojp.usdoj.gov/bjs/pub/pdf/csfcf00.pdf.

220. See Robinson \& Darley, supra note 186, at 457 (arguing that the criminal law's moral credibility is essential to effective crime control, and is enhanced if its application is perceived as "doing justice").

221. "The state's relative monopoly concerning the lawful use of physical violence requires legitimation.” Arenella, supra note 54, at 1533. 
arbitrary ways. $^{222}$ In the same vein, the state may publicly commit to a theory of or criteria for punishment, communicating the reassuring message that it is willing to see its power limited to particular cases and giving citizens the impression that they may be able to predict and control whether they are in jeopardy of punishment.

One especially effective legitimating strategy is making individual responsibility a prerequisite for punishment. ${ }^{223}$ By making individual responsibility a prerequisite for punishment, the state gives the citizen the empowering sense that it is "up to him" whether he will be punished at all. ${ }^{224} \mathrm{He}$ will only be punished if he chooses to do wrong; if he does wrong, but not by choice, he will not be punished (for he will not be "responsible" for his wrong). This is part of the appeal of the retributive approach to punishment: by making individual fault essential to punishment, it seems to give the citizen the ability to control whether the state will wield its terrible power against him. ${ }^{225}$ And this is the most celebrated feature of choice theories of punishment, which make responsible individual choice the sine qua non of criminal punishment. Thus, the state can go a long way toward legitimizing its exercise of the punishment power by making individual responsibility a prerequisite for criminal punishment.

But committing to a responsibility requirement entails a trade-off for the state. While anchoring the infliction of punishment in such criteria makes punishment more acceptable to the populace, it also limits the range of cases in which the state can punish. ${ }^{226}$ If discovered, breach of

222. See generally NORRIE, supra note 70 (discussing the legitimating function of commitment to rule of law). See also Arenella, supra note 54, at 1533 (discussing the legitimating function of commitment to due process).

223. See generally H.L.A. HART, PUNISHMENT AND ReSPONSIBILITY (1968) (suggesting that the choice theory of punishment is appealing in part because it protects citizens from excessive state interference with private lives); NORRIE, supra note 70 (noting that adopting a politically individualist approach to punishment legitimates state violence and reassures populace). See also Arenella, supra note 54, at 1533 (linking criminal punishment to a theory of moral responsibility results in "legitimation of state coercion"). "[P]erhaps all this legal rhetoric about 'just deserts' and moral responsibility is just the law's way of legitimating one form of human suffering that the state employs to defend itself." Id. at 1608 .

224. See HART, supra note 223, at 46-47 (noting that one of the benefits of a choice-based theory of punishment is that it gives citizens the reassuring impression that they can avoid punishment by making prudent choices); MOORE, supra note 1, at 549-52 (discussing Hart's view); Duff, supra note 56, at 149-50 (describing the basic tenets of choice theory). Public commitment to this sort of theory also creates a point of possible identification between the citizen and the state: the citizen is more likely to identify with a state that pledges allegiance to some criteria for punishment than with one that forswears any criteria for punishment at all, and if the state's theory of responsibility resonates with the citizen's, the citizen may feel a real kinship with the state. See Arenella, supra note 54, at 1533

225. NORRIE, supra note 70, at 206; Arenella, supra note 54, at 1532-33.

226. See NORRIE, supra note 70 , at 206 (retributive approach is both "legitimating" and 
such promises might trigger anxiety and alienation, diminish the perceived legitimacy of the state's violent acts, and increase the risk of popular criticism and resistance. Thus, when a state shores up its authority to punish by tying its exercise of that power to a responsibility requirement, its power to punish will be constrained by the conception of responsibility it adopts. The state will not be able to punish an actor who does not fit the state's conception of the responsible actor-at least not without calling into question the legitimacy of the state's exercise of the punishment power.

\section{Compatibilism, State Violence, and the Status Quo}

Because compatibilism and originationism take different approaches to criminal responsibility, they constrain the state's exercise of the punishment power in different ways. Assuming we have the ability to show causal connections between hard social conditions and human acts in a significant set of cases - an assumption I will address further below-the compatibilist approach will be more conducive to the use of state violence against the disadvantaged than the originationist approach. This, in turn, makes the compatibilist approach more solicitous to the existing social and political order.

I use the term "disadvantaged" in a generic sense. I mean to refer to those who share a certain set of hard circumstances-they live in substandard conditions, have fewer opportunities than most, and have little success influencing the political process. As the conventional wisdom goes, they are typically poor, they are likely to live in blighted urban areas or in undeveloped rural areas, they have impaired access to education and employment, and they are disproportionately - though not exclusively-people of color. ${ }^{227}$ Put another way, this is the group for whom hard social conditions are a chronic condition. This is also the group with the most reason to criticize and challenge the social order.

The retributivist criminal law, whether originationist or compatibilist, will always be a vehicle for state violence (in the form of punishment) against the disadvantaged, but the compatibilist criminal law is more conducive to such violence than the originationist criminal law. The reason has to do with the way the two approaches to criminal responsibility handle hard social conditions. As we have seen, originationism is receptive to claims that hard social conditions should

"limiting" to "state violence as punishment").

227. Delgado, supra note 11, at 23-37 (describing social conditions associated with disadvantage); Wright, supra note 71, at 480-83 (same). 
excuse. It is attentive to phenomena that shape desires and dispositions in gradual, holistic ways, as social conditions do. Compatibilism, in contrast, prefers to focus on the actor's features and capacities, and on phenomena that influence the actor in transitory and bizarre ways. As a result, compatibilism has little inclination to treat hard social conditions as excuses. The upshot is that in some cases, an originationist criminal law will excuse actors because of their exposure to hard social conditions while a compatibilist criminal law will not. ${ }^{228}$

It follows that the compatibilist criminal law will more frequently punish the disadvantaged. The disadvantaged are chronically exposed to hard social conditions. Assuming, as most criminal theorists do, that hard social conditions can play a causal role in antisocial conduct, some disadvantaged persons will be caused to commit antisocial acts by exposure to hard social conditions. In an originationist criminal justice system, such actors may be able to invoke an excuse grounded in their hard social conditions. A compatibilist criminal justice system, in contrast, will rarely, if ever, excuse disadvantaged defendants for such reasons. As a result, there will be a set of cases involving disadvantaged defendants in which an originationist criminal law will not authorize the state to inflict punishment while a compatibilist criminal law will. In short, compatibilism will authorize punishment of the disadvantaged more frequently than originationism will. ${ }^{229}$

Again, then, we come upon the compatibilist criminal law's secret politics. More willing to punish the disadvantaged, the compatibilist criminal law will be more favorable to and protective of the status quo. Punishment, of course, inflicts many sorts of losses on the punished person: it reduces opportunities for productive work, interrupts education and skill development, interferes with potentially productive social relationships, and catalyzes psychic changes that can undermine productivity (e.g., demoralization, depression, post-traumatic stress disorder, and other mental illnesses). ${ }^{230}$ It thereby reduces wealth,

228. Corrado, supra note 8, at 475-76 (the argument that "if a causal chain can be established between a deprived and abusive background and a particular crime in a particular case, then the crime ought to be excused . . . clearly presupposes incompatibilism and the causal theory" (i.e., originationism)). "The compatibilist has . . . no time . . . for an excuse based on a deprived and abusive social background .... The incompatibilist, on the other hand, would need only evidence that the criminal behavior was determined by the actor's background to believe that the behavior ought to be excused." Id. at 482.

229. Boldt makes a similar point about the compatibilist rejection of addiction defenses, which he says leads to disproportionate prosecution and punishment of defendants from "distinct, subordinated populations," such as African Americans and Hispanics. Boldt, supra note 188, at 2251

230. See WALLACE, supra note 13, at 200 (“[T] he practice of holding people responsible . . can 
diminishes opportunity, and retards social mobility for the punished person-and, more or less directly, for others in his family and community. Thus, because the compatibilist criminal law authorizes punishment of the disadvantaged at a higher rate than the originationist criminal law, it does more to perpetuate the disadvantaged status of the disadvantaged, and to entrench the existing social order. ${ }^{231}$

The compatibilist criminal law will also protect the existing social order in another way: it will be more conducive to violence against critics and opponents of the status quo than the originationist criminal law is. The disadvantaged are, of course, the group with the strongest motive to criticize and resist the status quo. Thus, we should expect to see the disadvantaged playing an important role in the generation of challenges to the social order. A compatibilist criminal law will, as we have seen, punish the disadvantaged at a higher rate than an originationist criminal law; as a result, it will more often authorize punishment against those who actually do challenge social order. Indeed, it may even be true that the compatibilist criminal law will more frequently authorize the state to punish disadvantaged actors for their criticism of or resistance to the status quo. ${ }^{232}$ An antisocial act may be an "indignant claim of right," or an objection to a legal regime perceived as unfair or unjust. ${ }^{233}$ It may be done to "prevent[] the justly treated members of society from being lulled into the belief that the existing system operates effectively for all members." 234 Because of "deep social alienation," "marginalized individuals [may] see themselves as locked in battle with the forces of order, so that getting away with behavior that harms others becomes the goal and refraining from such behavior becomes capitulation."235 In these cases, punishing antisocial acts is

be thought of as a system for distributing the benefits and burdens of human favor, leaving some people - the wrongdoers - notably worse off than others, insofar as they are subjected to the harms of censure, reproach, avoidance, withdrawal of esteem, and the like.").

231. Perhaps the compatibilist criminal law will also punish the advantaged at a higher rate than the disadvantaged, insofar as it will decline to recognize causal excuses with general application or uniquely available to the advantaged. Even if this is true, however, the effect is unlikely to offset the impact on disadvantaged communities, for the disadvantaged engage in potentially criminal antisocial conduct at a much higher rate than the advantaged do.

232. See Delgado, supra note 11 , at 70 (observing that society may "make the egoistic acts of criminals illegal because they conflict with the interests of the powerful, while the egoistic acts of the powerful are legalized," thus suggesting a system in which the feature that makes an act criminal is just that it threatens the social order preferred by the powerful).

233. NORRIE, supra note 70 , at 40 (observing that indignation about unjust property regimes has sometimes been a motive for certain crimes).

234. Delgado, supra note 11, at 60 (emphasis omitted). Morse is skeptical of this claim. See Morse, supra note 2, at 147 ("Most criminal behavior motivated by deviant subcultural values will not be intentionally political acts of civil disobedience or rebellion.").

235. GOLASH, supra note 128 , at 155 . 
punishing social criticism, and compatibilism will be more conducive to doing so than originationism.

Of course, all of this depends upon the premise that there is a set of cases in which compatibilism authorizes punishment against the disadvantaged but originationism does not. The argument so far has assumed that there is a set of such cases - namely, cases in which disadvantaged defendants are able to show that their antisocial acts are caused by hard social conditions to which they have been chronically exposed and which are not excusing in a compatibilist scheme. But is there such a set of cases?

If we are totally unable to show the causal connections between hard social conditions and antisocial conduct, the set of cases here will be empty. Likewise, the set will be empty if we are only able to show causal connections in cases involving the outrageous sorts of social conditions that also happen to trigger compatibilist excuses (poverty so extreme that actors must steal food to avoid starvation; 1984-style statesponsored mind control). Compatibilists are already committed to excusing in such cases. But if we are also able to show that less outrageous social conditions cause antisocial conduct, then there is a significant set of hard social condition cases that are excused in the originationist criminal law but not in the compatibilist criminal law.

And indeed, there is reason to believe we either already have the ability to give such causal explanations in a significant set of cases, or are on the verge of having this ability. One way to show this is to point to the progress that sociologists, psychologists, neurobiologists, and others have made in refining and developing their accounts of how various phenomena-including hard social conditions-catalyze antisocial conduct; academic philosophers have taken this tack. ${ }^{236}$ But there is also other evidence, closer to home for the criminal theorist, that suggests the same thing. The evidence I point to here is criminal theory's ongoing struggle to dispatch hard social-condition defenses.

236. Pereboom writes:

In recent decades, with advances in psychology, sociology, and neuroscience, the notion that certain patterns of human behavior may ultimately be due to factors beyond our control has become a serious cultural concern. In our society, the possibility that criminal behavior, for example, may be caused by influences in upbringing or by abnormal features of the brain is very much a live hypothesis. Furthermore, many people agree that criminals cannot be blameworthy for actions and tendencies produced in this way.

PEREBOOM, supra note 3, at xiii. "[L]awyers and judges are plainly interested in evidence showing that a person accused of a crime had no control over factors that led to it." Russell, supra note 18, at 249. 
The last thirty years have seen a steady stream of proposals to excuse actors for antisocial acts caused by hard social conditions. Criminal theorists and trial lawyers ${ }^{237}$ have proposed, for example, that we should excuse in cases of "urban psychosis,"238 "black rage,",239 and "involuntary rage" triggered by hard social conditions, ${ }^{240}$ that we should excuse those so "isolat[ed] from dominant culture" that they do not know dominant culture norms; ${ }^{241}$ that we should excuse actors who can show that, as a result of exposure to hard social conditions, they could not control their conduct on a particular occasion; ${ }^{242}$ and that juries "should hear evidence of a defendant's 'rotten social background' and decide for themselves whether it mitigates her culpability."243 Indeed, despite the law's

237. Falk collects numerous cases. Falk, supra note 128.

238. See id. at 738-41 (defense for defendants driven to mental illness or a "mindset of heightened fear and danger" by harsh or violent urban conditions).

239. See id. at 748-57 (defense for defendants made mentally ill or explosively sensitive to racial affronts by racial discrimination).

240. Delgado, supra note 11 , at 75-76, 85-87. Here, Delgado assumes that hard social conditions can make actors into "virtual "time bombs,", and that it is unjust to punish an actor when he is both turned into a "time bomb" and "triggered" by forces beyond his control. Id.; see also id. at 76 ("The kind of pent-up rage and despair that can result from living in a crowded, violent neighborhood can cause an explosion of violence just as disordered brain circuitry can.").

241. Id. at 76, 87-88. This excuse applies in cases where actors are raised in "cultural islands . . . with their own rules, norms and values," and would "require . . proof that the defendant did not adequately internalize the values of the larger society." Id. at 76; see also Wright, supra note 71, at 473-74 (arguing that knowledge of social norms is necessary to moral responsibility, and that "oppressed groups may . . . lack . . . relevant knowledge ... . [as a] result of governmental and societal failure to provide [such] ... knowledge . . . or adequate opportunity to acquire such knowledge").

242. Delgado, supra note 11, at 76-77, 88-89. This excuse "assumes that a rotten social background can cause inability to control conduct, as insanity does." Id. at 76-77. "My review of RSB and criminogenesis showed that inadequate nutrition, exposure to noxious substances, inadequate child-rearing practices, and constant stress can seriously impair a person's ability to conform his or her conduct to society's demands." Id. at 88-89. Bazelon favored an expansive version of the insanity defense: on his view, the excuse would apply when an actor's "mental or emotional processes or behavior controls were impaired to such an extent that he cannot justly be held responsible for his act." Bazelon, supra note 187, at 396 (emphasis omitted). For Bazelon, this test would allow for something approximating a social conditions excuse: he thought social conditions worked their criminogenic effect by creating mental abnormalities like "personality disorders." Id. at 394. If so, this test would "freely allow expert and lay testimony on . . . environmental, cultural, educational [and] economic . . . factors" on the "causes of . . . criminal behavior." Id. at 396. On socially primed insanity, see Falk, supra note 128, at 742-48, discussing a defense of media intoxication for defendants made mentally ill or driven to criminal acts by exposure to media violence.

243. Abbe Smith, Criminal Responsibility, Social Responsibility, and Angry Young Men: Reflections of a Feminist Criminal Defense Lawyer, 21 N.Y.U. REV. L. \& Soc. CHANGE 433, 465 (1994-1995). Smith also notes that members of subordinated groups should be able to present evidence of severe deprivation to the jury. Id. at 482. 
reluctance to explicitly grant such defenses, treatises and textbooks routinely cover such proposals in their discussion of excuses. ${ }^{244}$

This steady stream of proposals has been fueled by the sense that we either already have or will soon have the ability to show that some antisocial acts are caused by hard social conditions. Such ideas run through the whole body of literature. While proponents do not always explicitly ground their hard social-condition defenses in causal claims, ${ }^{245}$ they often provide extensive catalogs of causal accounts linking hard social conditions to antisocial conduct, ${ }^{246}$ and they recurringly suggest that when social conditions "cause" an act, this alone is enough to excuse the act. ${ }^{247}$ By the same token, the critics of these proposals consistently

244. See generally ANDReW Ashworth, Principles of CRiminal LAW (1991); SANFORd H. KADISH \& STEPHEN J. SCHUlHOFER, CRIMINAL LAW AND ITS PROCESSES (7th ed. 2001); READINGS IN CRIMINOLOGY AND PENOlOGY (David Dressler ed., 1964).

245. For example, on a narrow reading of Falk's urban psychosis, black rage, and media intoxication proposals, Falk is only proposing that the law recognize that certain social conditions can render a person insane. Falk shows that each defense has been used this way and approves the practice. See Falk, supra note 128, at 738-57, 783-98 ("These theories of defense fit within existing trends in the evolution of the self-defense doctrine."). Likewise, a narrow reading of Delgado's involuntary rage defense is that Delgado is only arguing that the law should recognize that certain social conditions can produce involuntary acts. Similar things can be said about Delgado's control defense and Bazelon's impairment defense.

Compatibilists are skeptical about claims that hard social conditions are relevant to their nonorigination criteria for blame and excuse. Moore, for example, reasons that such conditions generally do not render a person's act involuntary, or make a person incapable of practical reasoning, or subject an actor to the kind of hard choice that triggers excuse. MOORE, supra note 1, at 525-26, 534, 544-47. Morse makes a similar point: While "[m]any claim" that hard social conditions can "drive people crazy," and that it is possible to conceive social conditions so harsh that they coerce an actor, such cases will "rarely arise." Morse, supra note 86, at 1652-53; see also Morse, Reply, supra note 212, at 1255 (arguing that there is no "social consensus" that "background factors" are "relevant to legal responsibility"). Hard social conditions may shape character and predisposition, but they almost never create "defect[s] of volition, irrationality, external or internal coercion, or any other standard excusing condition." Morse, supra note 86, at 1653; see also Stephen J. Morse, Blame and Danger: An Essay on Preventive Detention, 76 B.U. L. REV. 113, 134 n.61 (1996) ("[M]ost defendants with a 'rotten social background' were rational when they offended and were not coerced to commit their crimes."); Morse, supra note 2, at 141-42 (arguing that hard social conditions will almost never rise to the level of genuine coercion); id. at 144 (arguing that hard social conditions almost never defeat "the general capacity to be guided by good reason"); Morse, supra note 26, at 374-75 (arguing that "new syndromes" are "rarely sufficient to justify a colorable claim of legal insanity").

246. Delgado, supra note 11, at 23-34; Falk, supra note 128, at 738-57.

247. Delgado, for example, writes, "In some cases, a defendant's impoverished background so greatly determines his or her criminal behavior that we feel it unfair to punish the individual. . . . [B]lame is inappropriate when a defendant's criminal behavior is caused by extrinsic factors beyond his or her control." Delgado, supra note 11, at 54-55 (emphasis added). Likewise, when Bazelon questions whether it is appropriate to blame "a poverty stricken and otherwise deprived black youth from the central city who kills a marine who taunted him with a racial epithet," or a "'modern Jean Valjean' who steals to feed his family," Bazelon, supra note 187, at 389, he says there is reason to doubt that "a free choice to do wrong can be found," $i d$., using "free choice" in a way that seems to oppose it to "causal relationship[s]" and "causal connections," $i d$. at 390-91. Bazelon appears to 
take for granted that causal explanations incorporating social conditions are possible. ${ }^{248}$ They concede that "deprivation or rotten social background" can "produce[] character flaws or antisocial predispositions," 249 and that "ghetto upbringing may give rise to intuitions of excuse." ${ }^{250}$ Indeed, they think causal explanations pointing to social conditions are not only possible, but so plausible that they threaten to lead us into the "cul-de-sac of . . . determinism."251 Thus, the critics do not challenge the assumption that we have the capacity to offer pertinent causal explanations; instead, they assail the "persistent but implausible claim" that hard social conditions "excuse[] because [they] cause[] criminal behavior." 252 "[C]ausation," they reiterate, "does not excuse." 253 In short, as far as both the proponents and critics are concerned, it is a foregone conclusion that we have or can have causal explanations involving hard social conditions. ${ }^{254}$

The persistent struggle over rotten-social-background defenses is, then, driven by the sense - common among criminal theorists - that we either have or will soon have satisfactory ${ }^{255}$ causal explanations linking

think that "disadvantaged backgrounds" cause crime by, among other things, cultivating "personality disorders." Id. at 394. Falk notes that proponents of such defenses have made arguments for reduction of culpability based on causation alone, primarily though not exclusively in the sentencing context. Falk, supra note 128, at 743-48.

At some points, Bazelon uses formulations that might suggest a compatibilist rather than originationist orientation, insofar as he suggests we can distinguish between excusing and nonexcusing causes. E.g., Bazelon, supra note 187, at 392-93. Most likely, however, Bazelon is an originationist who accepts the degree-determinist premise (namely, that some acts are "more or less free" than others). See MOORE, supra note 1, at 506-07 (characterizing Bazelon as a degree determinist).

248. The originationist nature of these claims is also recognized by noncompatibilists. See, e.g., Corrado, supra note 8, at 475-76 (noting that rotten-social-background defenses are essentially originationist).

249. Morse, supra note 86, at 1653.

250. MOORE, supra note 1 , at 545.

251. FLETCHER, supra note 54, at 801. Of course, determinism is only a cul-de-sac if (1) originationism is true (such that all nonoriginal conduct must be excused), (2) absolute determinism is true (such that all conduct is nonoriginal), and (3) universal excuse is in some way analogous to a cul-de-sac. While compatibilists attack the first proposition, the second and third are also vulnerable to attack. See Kaye, supra note 3, at 1131-57 (describing challenges to second and third propositions).

252. Morse, supra note 2, at 140.

253. Morse, supra note 86 , at 1653.

254. All the action in the debate about hard social-condition defenses is in the conflict between originationism and compatibilism.

255. Satisfactory, here, need not mean "genuinely complete." In our daily lives, most of us are willing to take detailed and intuitively plausible causal accounts of events (and acts) as satisfactory-for the purposes of both forward-looking prognostication and backward-looking explanation and moral judgment - even though our epistemic limits make it impossible for us to offer a genuinely complete causal account of any event or act. Partial accounts become proxies for the whole. 
hard social conditions to antisocial acts. ${ }^{256}$ In this light, criminal theory's preference for compatibilist criminal law has political significance. If we either have or will soon have the ability to generate social-causal explanations of antisocial acts in a significant set of cases, then the compatibilist criminal law either does now or will soon punish the disadvantaged at a higher rate than the originationist criminal law. That is, the compatibilist criminal law either is now or will soon be a better ally to the existing social order. It will be a better weapon for preventing the disadvantaged from acquiring the resources necessary for social mobility, and for quieting a pool of potentially vocal critics of the status quo.

\section{Conclusion}

Academic analysis of compatibilism rarely dwells on the theory's distinctive political features, but when criminal theorists import compatibilism into criminal theory some political features of compatibilism are brought to the surface. Ensconced as a critical cog in the machinery of the state, measuring and directing the state's use of the punishment power, compatibilism shows itself to be a strong ally to the status quo. As compared to the originationist alternative, it maximizes the state's ability to deter challenges to the social order. It does so both through ideological persuasion and through brute coercion.

\section{CONCLUSION}

Compatibilism, I have argued, is not politically innocent-at least not when it takes up residence in the criminal law. On the contrary, the compatibilist criminal law is a nice fit for a particular vision of the state - one in which the state is static and striated. Such a criminal law disrupts popular scrutiny of the relationship between social conditions and crime, and thus makes it less likely that the suffering and costs inherent in the crime problem will lead us to criticize or challenge the existing status quo; and it gives the state extra leeway to use its coercive power against the disadvantaged - the very class with the most incentive to challenge the status quo. In short, the compatibilist criminal law

256. The same can be seen in the generally undeveloped assumption that we are close to causal explanations based on "abusive background" and "genetic constitution" concrete enough to register in an originationist criminal law. See Corrado, supra note 3, at 1192 (discussing whether defenses based on such causal explanations make sense). 
contributes to the calcification of a hierarchical social order in a way that the originationist criminal law does not.

Uncovering this secret politics allows us to look at the compatibilist account of the criminal law in new ways. For one thing, it gives us a new vantage on whether we really have a compatibilist criminal law at all. On the one hand, we might think that the compatibilist criminal law's political features are normatively unappealing: they overvalue stable social hierarchy and undervalue alleviation of the crime problem (at least to the extent that they largely avoid contemplation of the ways in which social change might serve this purpose). While this may seem like a normative critique, it can also be cast as a critique of the descriptive claim: perhaps it is implausible that we would embrace a criminal law with this particular set of preferences. On the other hand, we might argue that the compatibilist criminal law's political features should be instrumentally appealing to social elites, insofar as the compatibilist criminal law is better suited than the originationist criminal law to preserve the social hierarchy and especially elite privilege. If we also take the view that the criminal law is created primarily by the most advantaged, we will find it entirely plausible that the criminal law adopts a theory of desert that serves to shore up the status of the social elite. ${ }^{257}$ On this view, the descriptive claim that we have a compatibilist criminal law gains plausibility.

This political critique leads to other, broader insights too. Seeing the politics behind the compatibilist account of the criminal law should remind us that our actual criminal justice institutions are themselves products of a political culture; and seeing this should remind us that our political culture is not pure and single-minded, but irreducibly pluralistic. If there is compatibilism in our criminal law, it is probably there in service (at least in part) to a certain politics; but if this is true, it is also probably true that there are other, competing threads in our criminal law, traceable (at least in part) to other, competing politics. As messy and conflicted as any other human institution, our criminal law likely has both compatibilist and originationist tendencies (alongside other overlapping and competing tendencies). This is why it is so difficult to prove we have a compatibilist criminal law, and this is why it is so difficult to prove we have an originationist criminal law. In fact, we have neither-because we have both. In our criminal law, irreconcilable compatibilist and originationist intuitions are intertwined.

257. See NORRIE, supra note 70, at 110 (self-serving "political interventions of the social élite" have played a critical role in shaping the law's "principles of responsibility"). 
If this is true, then claims that we have a compatibilist criminal law can be understood as efforts to elevate one of the criminal law's many jumbled tendencies (compatibilism) at the expense of others (like originationism), and this effort can be seen as driven by a particular politics. Seeing this - seeing the politics that lurks behind one contestant in the competition between theories of criminal responsibility-should clear the way for a more frankly political debate about criminal responsibility generally. In this reoriented debate, disputants will, of course, say what their preferred criteria for punishment are, but they should also say more. They should say, for example, whom their criteria will punish, and whom will be spared, identifying the punished not just in the politically opaque language of responsibility and desert, but also by reference to their role and status in the social order. They should say how application of their punishment criteria will influence the allocation of resources and power in society. And they should say why we should desire or approve a society that allocates resources and power in the way they recommend.

The political critique offered in this Article makes a start on that project: it contends that the compatibilist account of the criminal law resonates with an unappealing politics. The compatibilist criminal law seems to favor the status quo and the socially advantaged over social change and the disadvantaged. It diverts our attention from the causes of important social problems (the crime problem), and thus makes us less likely to solve those problems and less likely to have the society we actually want. In short, it prefers social rigor mortis over social mobility, and turns a blind eye to hard social conditions - and hard social problems - rather than facilitating change. These, I propose, are unappealing features for a criminal law. They suggest we ought not to let the originationist thread in our criminal law fall out. 